\title{
İstanbul'da Bir Üretim Mirası: 19. ve 20. yüzyıl Aralığında Aydınlatma Tasarımının Zamandizini
}

\author{
Zeynep FIRAT EZENCI ${ }^{1}$, Damla ALTUNCU²
}

\author{
${ }^{1}$ Haliç Üniversitesi, Mimarlık Fakültesi/ Endüstriyel Tasarım Bölümü, İstanbul, Türkiye \\ Orcid: 0000-0002-8322-1495 \\ ${ }^{2}$ MSGSÜ, Mimarlık Fakültesi, İç Mimarlık Bölümü, İstanbul, Türkiye \\ Orcid: 0000-0001-5276-2275
}

*Sorumlu Yazar e mail: zeynepfirat@halic.edu.tr

Geliş Tarihi: 11.06 .2021

Kabul Tarihi: 05.07 .2021

Atıf/Citation: Fırat Ezenci, Z., Altuncu, D. “İstanbul'da Bir Üretim Mirası: 19. ve 20. yüzyıl Aralığında Aydınlatma Tasarımının Zamandizini”, Haliç Üniversitesi Fen Bilimleri Dergisi 2021, 4/2: 123-172.

Araştırma Makalesi/ Research Article

\section{Bu makale Zeynep Fırat Ezenci tarafından, Mimar Sinan Güzel Sanatlar Üniversitesi Fen Bilimleri Enstitüsü İç Mimarlık Prog- ramı'nda Doç. Dr. Damla Altuncu danışmanlığında hazırlanan “Türkiye'de Aydınlatma Tasarımının Zamandizini: Şişhane Ör- neği” başlıklı doktora tezinden üretilmiştir.}

\section{$\ddot{O Z Z}$}

Elektrik enerjisi, sanayi devrimi ile birlikte yaklaşık son iki yüz yıldır aydınlatma alanında kullanılmaktadır. Ancak elektrik enerjisi kullanılmadan önce, farklı enerji kaynakları ile mekânlarda aydınlatma sağlanmıştır. Mekânları aydınlatabilmek için ise, çeşitli aydınlatma araçları kullanılmış ve zaman içerisinde evrim geçirerek farklı tasarımlarla karşımıza çıkmıştır. Aydınlatma kaynaklarının değişimi, aydınlatma elemanları üzerinden takip edilebilir olmuştur. Aydınlatma elemanlarının takibi yapılırken Osmanlı İmparatorluğu'nun içinde bulunduğu iktisadi, ticari ve ekonomik koşullar göz önüne alınmıştır. Aydınlatma yöntemlerinin ve araçlarının gelişimi, bu parametreler içerisinde değişip gelişmiştir. Bu çalışmanın amacı, yapay aydınlatmanın gelişimini Osmanlı İmparatorluğu'nun son dönemlerinde karar olarak aldığı sanayi kanunları ve sanayileşme politikaları çerçevesinde izleyebilmektir. Ayrıca Osmanlı İmparatorluğu'nun dağılması ve yeni kurulan Cumhuriyet' in etkisi ile değișen kaynakların izlerinin takip edilebilmesi amaçlanmıştır. Çalışma, Türkiye'deki aydınlatma gelişimini aydınlatma ürünleri üzerinden inceleyebilmek için sanayileşme 
hamlelerini takip ederek literatüre kazandırmaya önem göstermektedir. Bu amaç doğrultusunda aydınlatma aygıtı ve teknolojisi satışı yapan işletmeler, basılı yayınlar üzerinden takip edilerek harita üzerinde yoğunlaştıkları bölgeler tespit edilecektir. $\mathrm{Bu}$ sebeple çalışmanın problemi; Türkiye'deki aydınlatma aygitlarının gelişiminin işletme, üretici ve tasarımcı üzerinden kronolojisini oluşturmak için tasniflenerek topluma ve tarihe kazandırılmasına ihtiyaç vardır olarak belirlenmiştir.

Çalışma ile aydınlatma elemanlarının, aydınlatma kaynaklarının farklılaşması ile değişime uğradığı varsayılmaktadır. Ancak bu durumun belirlenebilmesi için öncelikle dönemlerin teknolojik gelişimlerinin sanayileşme üzerinden araştırılmasına ihtiyaç duyulmaktadır. Çalışma 1850-1940 yılları arasında sınırlandırılmıştır. Çalışmada, aydınlatma aygıtlarının çalışma prensipleri ile aydınlatma tasarımı gibi teknik konular kapsam dışında bırakılmıştır.

Anahtar Kelimeler: Aydınlatma Aygıtları, Osmanlı Devleti Sanayileşme Süreçleri, Aydınlatma Tarihi, Erken Cumhuriyet Dönemi, Tasarım Tarihi, Batılılaşma Dönemi

\title{
A Production Heritage in Istanbul: The Chronology of Lighting Design Between 19th and 20th Centuries
}

\begin{abstract}
Electrical energy has been used in the field of lighting for the last two hundred years along with the industrial revolution. However, before using electrical energy, different energy sources were used to provide lighting in the spaces. In order to illuminate the spaces, various lighting devices were used, and they evolved over time and appeared with different designs. The change of lighting sources can be followed through the lighting tools. While lighting tools were being tracked, the economic, commercial relations and economic conditions of the Ottoman Empire were taken into consideration. The development of illumination methods and tools has changed based on these parameters. The purpose of this study is to follow the development of artificial lighting within the framework of the industrial legislation and industrialization policies that were decided in the last periods of the Ottoman Empire. Furthermore, it is aimed to follow the traces of the changing lighting sources with the collapse of the Ottoman Empire and the effect of the newly established Republic. The study follows the industrialization moves in order to examine the lighting development in Turkey through lighting products. In accordance with this purpose, establishments that sell lighting devices and its technology will be followed through printed publications, and the regions where they are located on the map will be determined. For this reason, the aim of the study is to arrange and create a chronology of lightning devices based on enterprises, manufacturers and designers for the benefit of society and history.
\end{abstract}


With the study, it is assumed that the lighting elements change based on the differentiation of lighting sources. However, to display this, firstly it is necessary to research the technological developments of the periods through industrialization. The study is limited to the years of 1850-1940. Lighting devices' working principles and lighting design are out of scope in this study.

Keywords: Lighting Devices, Ottoman Empire Industrialization Period, Lighting History, Early Republican Period, Design History, Westernization Period

\section{Giriş}

Elektrik enerjisi, yaklaşık iki yüz yıllık bir dönemle birlikte hayatımızda yer almaktadır. Ancak elektrik keşfedilmeden önce aydınlatma araçlarında farklı kaynaklar kullanılmıştır. Öncelikle elde taşımaya müsait olan meşale, mum ve yağ lambası gibi basit aydınlatma araçları tercih edilmiştir. Daha sonra taşkömürü kullanılarak üretilen havagazı ile aydınlatan aydınlatma araçları kullanılmaya başlanmıştır. Elektrik enerjisi kullanılmaya başlandıktan sonra, havagazı ile aydınlatan araçlar elektrik ile aydınlatan araçlara doğru evrim geçirmiştir. Aydınlatmanın yaşam alanlarına girebilmesi için çeşitli aydınlatma aygıtlarına ihtiyaç vardır. Aygıtların teknolojiye bağlı olarak geçirdiği tasarım, malzeme ve üretim süreçleri; yakın tarihin iç mekân tasarım öğelerini bizlere sunmaktadır. Ancak aydınlatma aygıtlarının geçirdiğ değişimin izini sürmek için ülkenin sosyal, siyasi ve ekonomik durumu araştırılmıştır.

Aydınlatma aygıtları tasarımları hakkında tarih içerisinde yeterince çalışma ve bilgi bulunmamaktadır. Bu sebeple aydınlatma elemanları üzerinden yapılacak olan araştırmaların, tarihi araştırmalar doğrultusunda literatüre kazandırılmasına ihtiyaç duyulmaktadır. Fazlaca kullanılan ve tercih edilen bu ürünlerin tarihi planda ilerleyişi, üretim ve tüketici bazında bir gelişim süreci olarak ele alınıp değerlendirilmiştir. Konu araştırılırken birbiri ile yakın iki yaklaşımla birlikte ele alınacaktır. Bunlar; aydınlatma aygıtlarının tarih içerisindeki yeri ile iç mekânda tasarım öğesi olarak kullanımı şeklidir. İç mekânlarda 
tasarım öğesi olarak kullanılan aydınlatma elemanlarının satışını yapan işletmeler ve işletme sahiplerinin bulunması hedeflenen olmuştur. Bu işletmelerin 1880-1930 yılları arasında kümelendikleri bölgelerin tespiti ticaret yıllıkları ve haritalar ile oluşturulmuştur.

Aydınlatma aygıtlarının çok sayıda kullanımı ve zaruri ihtiyaç olarak ele alınması sebebiyle araştırılmaya ihtiyaç duymaktadır. $\mathrm{Bu}$ sebeple aydınlatma aygıtlarının tarihsel süreç içerisinde tanımlarının yapılarak topluma kazandırılması gerekmektedir. Ancak bu çalışmada aydınlatma aygitlarının geçirdiği değişim, ülkenin sanayileşme hamlelerinin takibi üzerinden yapılmıştır.

Ülkenin içerisinde bulunduğu dönem itibariyle çeşitli sanayi kanunları ve sanayileşme politikaları gündeme gelmiştir. Sanayi devrimi ile Osmanlı İmparatorluğu sanayisi büyük ölçüde etkilenmiştir. Bu durum, zanaat ile uğraşan esnaf teşkilatlanmalarını doğrudan etkileyerek değişimlere sebep olmuştur. Çalışmada, esnaf teşkilatlanmalarının Osmanlı Devleti içerisindeki rolü ve etkisine değinilmiştir.

Aydınlatmanın Türkiye'deki dönemleri itibariyle yapılan literatür taramasında genel olarak iktisat tarihi alanında yapılan çalışmalar ortaya çıkmıştır. Semiz'in [1] Türkiye'deki sanayi alanı içerisinde yaptığı iktisadi araştırmasında; Osmanlı İmparatorluğu'nun küçük işletmeler vasıtası ile kalkındığından ve bu sayede birçok alanda Avrupa ile üretim konusunda rekabet edebildiğinden bahsetmiştir. Tezin kapsamına küçük üretici ve işletmecilerin zanaat kaynaklı olduğunun bir göstergesi üzerinden aydınlatma üreticilerinin izlenmesine yardımcı olacağ1 düşünülmüştür.

Çalışmanın aydınlatma gereçleri bakımından incelenmesinin planlandığ 1 bölümde ise; Karahüseyin'in [2] belirli bir dönem içerisinde yer alan ve saraylarda kullanılan aydınlatma elemanlarının tasnifi üzerinden derlediği çalışmasının aydınlatma ürünlerinin tanımlanmasında yol gösterici olacağı düşünülmektedir. Karahüseyin [2] elektriğe geçiş ile üretilen yeni tasarımlara değinmiş ve şöyle devam etmiştir; 
“Avizeler, erken devirlerden başlayarak dönemin koşullarına göre ve ihtiyacın karşılanması doğrultusunda yalnızca aydınlatmaya yönelik şekilde tasarlandığı halde tarihi süreç içinde, teknolojinin gelişmesi, yüzyılın sanat anlayışı ve estetik kaygıların da göz önünde tutulmasıyla muhteşem avizelerin tasarımı gerçekleşmiştir.”

Oral'a [3] göre aydınlatma ürünleri; Osmanlı'nın gündelik hayatına modernleşme ve batılılaşma döneminde girmiştir. Sanayi devrimi ile gelişen Batı'dan çeşitli ürünler ithal edilerek ülkemize giriş yapmıştır. Bu ürünleri başta refah seviyesi yüksek kişiler satın almaya başlamış, ancak zaman içerisinde halkın tüm tabanlarına yayılmıştır. Bu sebeple çeşitli ilanlar vasıtasıyla araştırılan mamuller, modernleşme sonrası olan ürünlerdir.

Çalışmada, Osmanlı Devleti'nin sanayileşme politikalarının esnaf teşkilatlanmalarına olan etkisi incelenirken, aydınlatma elemanı üretim ve ticareti ile ilgilenen esnaf teşkilatlarına ulaşılabilmesi için bir araç olacağı düşünülmektedir. Esnaf teşkilatlanmaları içerisinden ehl-i hiref topluluğunu Mortan ve Küçükerman [4] "üretimde seçkin ve yaratıcı çözümler getiren bir öncü grup” olarak değerlendirmişlerdir.

Aydınlatma aygıtlarının satışını ve ticaretini yapan işletmelerin tespitinin yapılabilmesi için Fransızca yayınlar taranmıştır. Bu yayınlar içerisinde Şark Ticaret Yıllıkları olarak bilinen ve 1868-1945 yılları arasında düzenli olarak yayınlanan ticaret yıllıkları ile Şam Rehberi ve Ameli Elektrik dergisi incelenecek yayınlar yer almaktadır.

Aydınlatma aygıtı ticareti yapan işletmeler belirlendikten sonra Charles E. Goad'un 1905 yılına ait sigorta haritasında 10'ar y1llı periyotlar ile yoğunluk haritası oluşturulmuştur.

Araştırmanın amacı, 19. ve 20. yüzyılda aydınlatma üretici ve tüccarlarının İstanbul'da yer alan üretim mekânlarını takip ederek ekonomik ve sosyal açıdan geçirdikleri evrimi ortaya çıkartmaktır. Bu çalışma ile üretim alanlarının konumlandığı bölgelerin farklı bağlamlar ile arka planının açıklanması ve daha net anlaşılmasını sağlayacağı hedeflenmiştir. 


\section{Materyal ve Metot}

Dünyada yaşanan olaylar, yer ve zaman olarak değil, oluşma tarzı ve içinde yer alan kişi ve kurumlar bakımından farklılık göstermektedir. Tarihi olayların çözümlenebilmesi için, konunun derinliklerine inilip araştırılmasına ihtiyaç duyulmaktadır [5].

$\mathrm{Bu}$ çalışmada tarama modeli ele alınmıştır ve genel tarama modeli ile çalışmanın evreni, yapay aydınlatma aygıtlarının gelişimi olarak belirlenmiştir. Burada örneklemi belirlemek için dikey örneklem yöntemi tercih edilmiştir. Dikey örneklem, genelden özele doğru giden bir yöntemdir [6].

Örneklem, kendi içerisinde bulunan değişkenlere göre alt gruplara ayrılmaktadır. Bu alt gruplardan eleman örnekleme yöntemiyle içerlerinden elemanlar alınmaktadır. Elemanların hepsi eşit orantıda olmalıdır. Bu yönteme oranlı eleman örnekleme denmektedir [7]. Çalışmada örneklemenin inceleneceği teknik bu şekilde belirlenmiştir.

Çalışmada öncelik, konuya bütüncül yaklaşarak Osmanlı Dönemi sanayileşme hamleleri üzerinden Osmanlı esnaf ve sanayisine ulaşmak hedeflenmiştir. Ardından kronolojiyi oluşturabilmek için çeşitli kaynakların ve belgelerin taranmasına ihtiyaç duyulmaktadır. Bu sebeple bir veri toplama tekniği olan belgesel tarama yöntemi ile kronolojiyi oluşturacak olan çalışmaların taranması amaçlanmıştır. Belgesel tarama, var olan belgeleri ve kayıtları irdeleyerek ortaya çıkan verileri toplamaya yardımcı olan bir yöntemdir. Bu yöntem dahilinde; çeşitli fotoğraflar, ses ve video kayıt cihazları, bina gibi kalıntılar, olaylar gerçekleştikten sonra kayıt altına alınan ve yazılı hale dönüştürülen çeşitli mektuplar, raporlar, kitaplar, ansiklopediler, resmi ve özel yazılar, istatistiki belgeler, anılar, tutanaklar, resmî gazete belgeleri, yaşam öyküleri vb. kayıtların taranması planlanmıştır [7].

Araştırmanın konusu olan aydınlatma aygıtı üretici ve tüccarlarını araştırırken dönemin yeni teknolojisi olan elektriğin, aydınlatma ürünlerinde ürün çeşitliliğine ve satışına etki ettiği düşünülmektedir. Benzer bir durumun Osmanlı sanayisinin gelişim ve değişimi ile esnaf 
teşkilatlarındaki ürün çeşitliliğgi ve ticaretinin değişimleri üzerinden ele alınması planlanmıştır. Sosyolojik olarak konu ele alındığında ise, mekânsal olarak aile yaşantısı içerisinde aydınlatma ürünlerinin değişip çeşitlenmesinin yeni bir yaşantı biçimini ortaya çıkarttığı varsayılmaktadir.

Çalışmanın araştırma problemi doğrultusunda yapılan incelemesinde, nitel veri toplama tekniğinden tarih araştırması yöntemi kullanılmıştır. Bu çalışmada tarih biliminin araştırma yöntemi irdelendiğinde, geçmişte gerçekleşen olgular üzerinden ele alınmaktadır. $\mathrm{Bu}$ olguları ise Karakaya [8] şöyle değerlendirmiştir;

1) Geçmişte yaşananlar,

2) Olan olaylardan etkilenenler,

3) Olayların gerçekleşme durumu,

4) Ortaya çıkan sonuçların değerlendirilmesi,

5) Sonuçların nasıl ve kimleri etkilediği.

Üzerinden bir çıkarım ile bu çalışmada yöntem üzerinden değerlendirilmiştir.

Bu çalışmanın araştırma problemi: "Türkiye'deki aydınlatma aygıtlarının gelişiminin işletme, üretici ve tasarımcı üzerinden kronolojisini oluşturmak için tasniflenerek topluma ve tarihe kazandırılmasına ihtiyaç vardır" olarak belirlenmiştir.

\section{Bulgular ve Tartışma}

\subsection{Türkiye'de Değişen Enerji Kaynakları ve Topluma Etkisi}

İçinde bulunulan fiziksel ortamın gereksinimlerini karşılayacak aydınlatma aygıtlarının, yaşanılan mekân ve çevreyi uygun ve doğru bir biçimde aydınlatmak, eski çağlardan itibaren hedeflenen olmuştur.

Çeşitli aydınlatma yöntemleri ve araçları kullanılmış, yıllar içerisinde gelişmiş ve evrilmiştir. Gün 1şı̆̆ının yetersiz kaldığı durumlarda yapay kaynaklar devreye girmiştir. Yapay kaynaklar, zaman içerisinde ve dönemsel koşullar dahilinde gelişmiştir. Gelişen her yeni teknolojiyle aygıtlar değişime uğramış ancak dönemlerin ekonomik koşulları 
ve üretim kapasiteleri yüzünden yeni ürünler yerine üretilmiş olanların yeni teknolojilere adaptasyonu sağlanmıştır.

1839 yılında Sultan Abdülmecid tahta çıkmış ve aynı yıl Tanzimat Fermanı yayınlanmıştır. Tanzimat ile Osmanlı Devleti, Batı devletlerine yakınlaşmak için büyük bir adım atmıştır. Tanzimat döneminde yapılan birçok yenilik, Osmanlı Devleti'nde değişimlere sebep olmuştur. Tanzimat devri ile sanayileşme hızlanmış ve bu sayede çeşitli kurumlar ve fabrikalar kurulmaya başlanmıştır.

1839 yılında Tanzimat Fermanı'nın ilanı ile Batı'daki yeni teknolojik gelişmeler, imparatorluk bünyesinde uygulanmıştır. 19. yüzyılda kabul edilen teknolojik gelişmelerin mekânların aydınlatılmasına katkısı büyük olmuştur. Bu sayede mekânlar hava gazı ile aydınlatılıp, 1sitılmaya başlanmıştır [9].

Batı'da sanayi devrimi ile yaşanan gelişmeler ile mekânların aydınlatılması ön plana çıkmıştır. Avrupa' da yönetimlere ait olan büyük yerleşim alanlarında hava gazı ile aydınlatma uygulamaları yapılmıştır. Avrupa'da saray gibi büyük ve gösterişli yapıların aydınlatılması ile Osmanlı Devleti'nde yer alan büyük yapıların benzer bir havagazı sistemi ile aydınlatma örneği görülmüştür [10].

İstanbul'da ilk havagazının kullanımına Dolmabahçe Sarayı'nın aydınlatılması ile başlanmıştır. Sultan Abdülmecid'in emri ile Dolmabahçe Gazhanesi kurulmuştur. Dolmabahçe Gazhanesinin yıllar içerisinde yeterli gelmeyişi ile Beylerbeyi ile Kuzguncuk arasında bir gazhane daha kurulmuştur. Bu gazhane ile Beylerbeyi Sarayı aydınlatılmıştır [10]. 19. yüzyılda havagazı ile aydınlatma yerini elektrik enerjisine bırakmıştır. Elektrik ile aydınlatma, Osmanlı Devleti'nde teknoloji yönünden köklü bir değişime yol açmıştır.

Havagazı sistemine uygun olarak işlevini devam ettiren aydınlatma elemanları, elektriğe geçiş ile yeni bir anlatım dili oluşturmuşlardır [10]. Bu durum ile Osmanlı Devleti'nin teknolojik değişimi vurgulanmıştır.

Osmanlı Döneminde İstanbul şehri, en son ve en uzun süreli başkent olmuştur. Şehrin başkent olmasının getirdiği siyasi, ekonomik, 
sosyal ve kültürel etkilerin mekânsal dönüşümlerde çeşitli etkileri olmuştur. Osmanlı Devleti'nin taşıdığı doğu kültürünün etkileri, Batı'dan gelen yenilikçi akım ile birleşmiş ve bu durum mekânlarda çeşitli gelişim, değişim ve dönüşümler olarak görülmüştür.

Osmanlı'da başlayan modernleşme ve batılılaşma hareketleri, öncelikle saray ve saray eşrafinın yaşadığ 1 yerlerde görülmüştür. Avrupa'dan saray için özel olarak getirtilen mimarlar ve dekoratörler ile batılılaşma süreci hızlanmıştır [11].

Osmanlı Devleti'nde, halkın yaşadığı konaklar ile çağdaş konutların iç mekânlarındaki mobilya tarzlarındaki değişimin sebeplerinden biri, Mısır'dan İstanbul'a gelen Osmanlı'nın üst düzey kişilerinin Boğaziçi'ne yerleşmesi gösterilebilir. Buraya yerleşenler, yaşadıkları mekânları Batılı tarza uygun şekilde döşemişlerdir. Değişimin bir diğer sebebi ise Kırım Savaşı dolayısıyla İstanbul'a gelen Fransız ve İngiliz askerlerinin kendi yaşam tarzlarını beraberlerinde getirmeleridir [12].

Saraya uygun Avrupai model mobilyaların üretimi Levantenlerin yoğun olduğu Pera ve çevre yerleşim bölgelerinde başlamıştır. İthal edilen modellerin ise Osmanlı gelenekselliğine yakın olması adına yeniden tasarlanması gerekmiştir.

Pera ve Galata bölgesi içerisinde yaşayan Gayrimüslim Osmanlı vatandaşlarının ya da yabancı elçilerin sosyal aktivitelerinin yoğunlaştığ 1 19. Yüzyılda çeşitli davetler verilmeye başlanmıştır. $\mathrm{Bu}$ davetler yaşam alanlarında veya davetlere uygun olabilecek geniş ve büyük mekânlarda organize edilmekteydi. Organizasyondan, yabancı ülkelerin elçileri ve Gayrimüslim vatandaşların kurdukları dernekler sorumlu olmaktaydı. Davetlerin yaygınlaşması ile iç mekânlarda çeşitli dönüşümler başlamıştır. Bu dönüşümlerin başında lüks tüketim ile bağdaşan çeşitli ürünlerin satışı ve tedariki yer almaktadır.

Derin Öncel'in [13] 4 Şubat 1865 y1lına ait Journal de Constantinople gazetesinden çevirdiği ilanın bir kısmında Beyoğlu bölgesinde yapılan sosyal aktivitelerden bahsedilmiştir; 
"Pera halkının eğlenceleri devam etmektedir. Bazı kayıplar ve yas dolayısıyla cemaatlerin salonları kapalı olsa da, bölgenin ileri gelenleri evlerini çeşitli davetler için açmaktalar. (...)

Son olarak M. G. Guarracino ve ailesi tarafindan aile dostlarına verilen davetten söz etmek istiyoruz. Bu davet bir balo değildi ama orkestra, parlak 1şıklar ve tuvaletler göze çarpmaktaydı. (...)"

Gazeteye verilen bu ilanda bahsedilen parlak 1şıklar ile mekânlar içerisindeki dönüşümlere bir gönderme yapıldığı varsayılmaktadır. Bahsi geçen sosyal aktivitelerin mekânlara olan yansıması ancak ihtişamlı ürünler ile sağlanmaktadır. Parlak ışıklar için gereken lüks tüketim ürünü olarak aydınlatma ürünlerinden bahsedildiği düşünülmektedir.

Akın'ın [14] belirttiği üzere; Pera'da ikamet edenler, verdikleri büyük davetler vasıtasıyla salonlarını ve evlerini Avrupa modasına uygun bir dekorasyon ile biçimlendirme hevesindelerdi. Bu sebeple Fransız ve İtalyan işi sandalye, kanepe ve oturma elemanları satan dükkan ilanlarına sıkça rastlanmaktadır. Ayrıca, salon mobilyalarının bütünleyicisi olan ve çok seçkin Avrupa şehirlerinden gelen (Paris, Londra vb.) cam, porselen, bronz ve bakır ev eşyaları da o dönem içerisinde revaçtadır. Benzer bir ilan Şekil 1.'de görülmektedir.

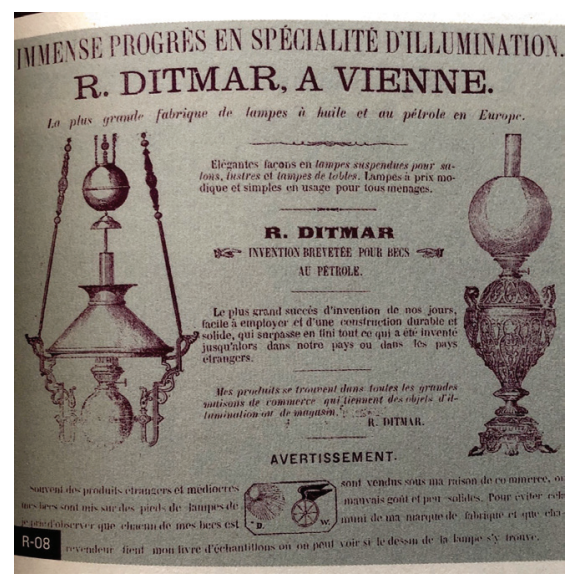

Şekil 1. R. Ditmar Wien marka petrol lambası satış ilanı [14]. 
Osmanlı'da lüks ve Batılılaşma göstergesi olan aydınlatma elemanlarının zengin konaklarda, saraylarda ve elçiliklerde kullanılması ile; alım gücü yüksek olan üst tabakanın ulaşabildiği ürünler olduğu söylenebilmektedir.

Osmanlı Devleti'nin 1850 yılından itibaren batılılaşma sürecine girmesi ile Avrupa'da hız kazanan Sanayi devriminin tüketim etkilerini hissetmeye başlamıştır. Tüketici, yeni ve sanayi mamulü olan ürünleri talep etmeye başlamış ve bu durum ithal ürünlerin ülkeye girişini hızlandırmıştır. Osmanlı Devleti'nin klasik aydınlatma elemanları olan; çıra, mum, şamdan, kandil ve fenerlere ek olarak Batı'dan ithal lambalar evlerin dekorasyonuna zaman içerisinde katılmıştır. İthal edilen ürünleri önce belli bir zümre kullanmış, ardından halk yavaş yavaş geleneksel öğeleri bırakarak ithal öğelere yönelmiştir. Lamba kelimesi Grekçe lampas/lampa kelimelerinden dilimize girmiştir ve meşale kelimesinin kökenidir [3].

Oral [3] ithal aydınlatma elemanlarının ülkedeki artışı ile ilgili olarak, okuryazarlığın arttığını belirtmiştir. Bunun sebebini ise, geleneksel aydınlatma elemanlarında kullanılan ateşleyici sisteminin ithal olanlara kıyasla yetersiz olmasıdır. Yetersiz kalan ateşleyiciler ile aydınlatma, istenilen oranlara ulaşamamaktaydı ve kaliteli bir aydınlatma sağlamamaktaydı. Batılı ve teknolojik aydınlatma elemanlarının artışı ile okuma oranı doğrusal olarak artmıştır. Bu sayede iç mekânda yaşam konforu artmış ve ailelerin bir arada daha fazla zaman geçirmesine olanak sağlamıştır. Aynı zamanda iç mekânda estetik zevkin gelişmesi ve yenileşmesine ön ayak olduğu söylenebilmektedir.

Osmanlı toplumunun, aydınlatma sayesinde okuryazarlığının gelişerek ülke insanının modernleşmesi, kadın ve erkeğin aile içindeki rollerin modern normlara göre yeniden tanımlanmasının önünü açmıştır.

İç mekânda kullanımı tercih edilen ürünler; mumlar, şamdanlar, kandiller, yağ lambaları, gaz yağı lambaları ve havagazı lambaları gösterilebilmektedir. Mekân içerisinde kullanılan bu aydınlatma elemanları içerisinde tehlike arz eden ürünler olduğu kadar, güvenliğin nispeten sağlandığı ürünler de mevcuttur. 
19. yüzyılda cam teknolojisinde yaşanan gelişmelerin, aydınlatma sistemlerinin gelişip ilerlemeye başlaması ile bir bağlantısı bulunmaktadır. Bu döneme kadar kullanılan camlar, özellikle gaz lambası için kullanılan camlar, yeterli gelmemekteydi [15]. Dayanıklı ve farklı üretim yöntemleri ile üretilen camların kullanımı ile aydınlatma ürünleri çeşitlenmiştir.

\subsection{Aydınlatmanın İstanbul’daki Tarihi Gelişimi}

Elektriğin Türkiye'ye gelişinden evvel aydınlatmada kullanılmak üzere çeşitli enerjilerden ve yöntemlerden yararlanılmıştır. Osmanlı Devleti'ndeki enerji çeşitlerinin güncellenmesi ve gelişmesi sanayi devriminin gelişi ile başlamıştır.

1838 y1lında Osmanlı Devleti ve İngiltere arasında imzalanan Baltalimanı Ticaret Anlaşması ile Osmanlı sanayisinde yeni bir dönem başlamıştır. İngiltere ile yetinmeyip diğer Avrupa ülkeleri ile benzer sanayi anlaşmaları yapan Osmanlı Devleti, Avrupa'nın sanayi malları için açık bir pazar konumunda yer almıştır [16].

Osmanlı Devleti döneminde sokakların aydınlatılmasına 1846 y1lında alınan bir kararla geçilmiştir. Bu kararda ev ve dükkanlara fener asma zorunluluğu gelmiştir. Fakat yetersiz kalan denetimler sonucunda bu karardan vazgeçilmiştir. Sokaklarda tekrardan bir güvensizlik ortamının oluşmaması adına yeniden bir karar alınmıştır. Bu karar, aydınlatmanın o dönem içerisinde ihale usulüyle verilmesidir. İlk imtiyaz, 1864 yılında Heres isimli bir yabancıya sokakların gaz yağı ile aydınlatılması için verilmiştir [17].

1846 yılında Osmanlı Devleti izniyle Pera'nın (Beyoğlu) aydınlatılması ve Avrupai bir görünüme sahip olması hedeflenmekteydi. Galata ve Pera'nın yeterince aydınlatılamaması, Avrupa'da yer alan Paris, Londra gibi şehirlere benzetilmesi için çözülmesi gereken bir sorun olarak gözlemlenmekteydi. Bu sebeple hava gazı ile aydınlatılmaya başlanmıştı ve hatta yer yer elektrik kullanımları da gözükmekteydi [14]. 
Elektrik enerjisi, Osmanlı döneminde ilk kez Sultan II. Abdülhamid döneminde ülkeye gelmiştir [18]. Ancak II. Abdülhamid, kendisine karşı kullanılacağına inandığı için, teknolojik aletlerden ve yeni gelişmelerden uzak durmuştur. Bu sebeple elektrikli tramvay, telefon, elektrikli aydınlatma cihazlarının kullanımı yasaklanmıştır. Amerika Birleşik Devletleri'nden ithal edilen lambalara gümrükte el koyulmuştur. Bu yeni tip lambaların ülkeye giriş izni için II. Abdülhamid'in kişisel güvenini kazanmış Batılı ithalatçılar devreye girmişlerdir [19].

1898 yılında Yıldız Sarayı'nın içerisinde bulunan Şale Köşkü’nde elektrik ile aydınlatmanın sağlanabilmesi için gerekli elektrikli donanımlar Siemens şirketi tarafından kurulmuştur [20].

Küçükerman'a [20] göre, saray için temin edilecek olan aydınlatma ürünlerinin belirtildiği imzalı mektupta şöyle denilmiştir;

"Sarayın bu özenli mekânlarına konulacak donatımın ve lambaların listesi içinde çok sayıda 'torcheres Beicos bronze' 'Beykoz bronz 1şıkl1k' veya 'lustre grand Beicos' (büyük Beykoz avize) ya da 'suspension Fanal de Beylerbey' (Beylerbeyi avizesi) gibi tanımlar vard1. Mektup, 'Siemens \& Halske İstanbul Acenteliği'nin verdiği teklifin kabul edildiğini bildiren 'Le President Selim Melhame' imzası ile son buluyordu.”

1850 yılından itibaren Osmanlı Devleti, sanayileşme hareketleri göstermeye başlamış ve sanayide ilerlemiş olan diğer Avrupa ülkelerine yakınlaşmaya çalışmıştır. Bu sebeple sanayileşmede öncelik olarak ordunun ihtiyaçları ve devletin istekleri doğrultusunda ilerlenmiştir [21].

19. yüzyılın son 50 senesine bakıldığında ise Batı'da elektrik enerjisinden yararlanılmaya başlanmıştır. Elektriğin yaygınlaşması ile elektrik santralleri kurulmuştur. Ancak aynı dönem içerisinde Osmanlı Devleti'nin çöküş yıllarıydı ve savaşların etkisi ile yanlış yönetilen ekonomi politikaları gündemdeydi. Bu sebeple elektriği yaygınlaştıracak santrallerin kullanılması yerine, ülkede gazhanelerden alınan enerji kullanılmaktaydı. 
Yeni sanayi politikalarının ülkeye gelmesiyle birlikte, aydınlatma elemanlarında havagazlı aydınlatma araçları ve petrol lambaları kullanılmaya başlanmıştır [22].

\subsection{Cumhuriyet Öncesi Dönem İçerisinde Yapılan Düzenlemeler (1853-1923)}

Sanayi Devrimi ile Batı'da yeni bir değişim rüzgârı başlamıştı. Batı'nın kendine yeni bir sanayi pazarı arayışı sonucunda Osmanlı Devleti yeni bir açık pazar konumuna gelmiştir [23]. 1815 yılından itibaren Avrupa'da üretilen mallar Doğu'ya doğru gelmeye ve bu bölgeyi etkilemeye başlamıştır. Avrupa'da üretilen mallar gittikçe çoğalmış ve geleneksel Osmanlı imalatını olumsuz yönde etkilemiştir. Geleneksel Osmanlı ürünlerini üreten ustalar işsiz kalmış bu sebeple devlete olan vergi kaynakları azalmıştır. Vergilerde yaşanan azalma ile Osmanlı devleti maliyesinin Avrupa'nın kontrolüne girerek bağımsızlığını yitirmesine sebep olmuştur [24]. Osmanlı Devleti'nin açık bir pazar haline gelmesi ile Tanzimat sonrası yeni sanayileşme politikaları oluşmuştur.

Osmanlı Devleti, 19. yüzy1lın ilk 50 senesi içerisinde sanayi devriminin Batı'dan gelen etkilerini devlet tarafından girişimlerle karşılamaya çalışmaktaydı. [25].

Osmanlı İmparatorluğu 19. Yüzyıldan itibaren el işi ve emeğine dayanan küçük işletmeler ile gereksinimlerini karşılayabiliyordu. 1800'lü yılların başında el emeğine bağlı olarak büyüyen ve gelişen küçük işletmeler Avrupa ile rekabet edebilecek durumdaydı. Fakat Avrupa'da başlayan sanayi devrimi ile bu durum hızla tersine dönmüştü. Osmanlı Devleti, gelişen teknolojiye ayak uydurmakta zorlanırken, sanayi devriminde üretilen Batılı ürünler ile rekabet edemeyecek bir boyuta gelmişti. Sanayi devrimi ile teknolojiyi yakalamaya çalışan fakat savaşların etkisi ile ekonomik, siyasal ve sosyal olarak çöküşe doğru giden Osmanlı Devleti, küçük işletmelerin de artık kendisine yetememesi sebebiyle tüketicinin taleplerine yeterince karşılık verememekteydi. 
Açık pazar haline gelen Osmanlı sanayisinde 15. Yüzyıldan itibaren varlığını sürdüren esnaf loncaları 19. Yüzyıl itibari ile büyük darbe almıştır. Bunun sebebi ise eski usul tekniklerle üretime devam eden loncaların sanayi devrimi ürünlerine ve açık pazar rekabetine karşı koyamayış1 olmuştur [26]. Esnaf birliklerine bağlı yetişen kişiler, küçük yaşlardan itibaren mesleki ve toplumsal geleneklere bağl1lık içerisinde yetişiyorlardı. Bu sebeple klasik Osmanlı esnaf ve tüccar tipolojisi ile Avrupa'da yetişen veya Avrupa geleneklerine bağlı tüccar ve esnaf s1nıfı birbirinden farklıydı. Osmanlı esnaf teşkilatlarına bağlı olan bu kişilerin geleneklere bağlılıkları sebebi ile Avrupalı tüccarlardan farklı kazanç eğilimleri gözetmekteydiler. Bu sebeple kaliteli iş yapmanın peşinden gidilmiş ve bu uğurda özellikle imalat aşamasında ağır ve titizlikle çalışılmıştır. Fakat zaman içerisinde siyasi ve ekonomik değişimler ile yabancı tüccar ve yatırımcılar karşısında rekabeti koruyamaz hale gelmiştir. Bu sebeple Osmanlı esnafı hızlı ve hazır üretim ürünler karşısında gücünü kaybetmiş ve küçülmüştür [27].

Ülkedeki genç bürokratlara göre Osmanlı Devleti’nin kurtuluşu, Avrupa ve Dünya pazarı ile bütünleşme ile olabilirdi. Bu sebeple 1838 yılında önce İngiltere, daha sonra diğer büyük devletler ile yapılan ticari anlaşmalarla sanayileşme girişimleri oluşmuştur. Anlaşmalar ile Avrupalılar resmi yetkililerin aradan çekilmesi ile yerli üreticiyle doğrudan irtibat kurma şansını yakalamıştır. Gümrük vergileri Avrupalı tüccarlar için indirilmiştir. Dış ticaretteki bu atılım ile orta sınıf tüccarların ülkeye soktukları ucuz sanayi ürünleriyle yerli esnaf rekabet edememiștir. Ancak Osmanlı limanları ve özellikle Osmanlı'nın başkenti ticaret atılım ile yabancı topraklardan gelen tüccar ve iş adamlarının uğrak bir merkezi haline gelmiştir [19].

Devlet ağırlıklı fabrikaların kurulması, işletmelerin açılması ve yeni yatırımlar, 1800'lü yıllarda başlamış ve 1830'lu yıllarda en yoğun dönemini geçirmiştir [28].

Osmanlı Devleti'nin sanayileşmesinde önemli yer tutan fabrikalar cam, porselen ve çini fabrikalarıdır. I. Abdülmecid'in emriyle 1840 yılında Çubuklu Billur Fabrikası (Çini ve Billur Fabrika-i 
Hümayunu) kurulmuştur [29]. Beykoz, Çubuklu 'da kurulan fabrikanın ürettiği Beykoz işi ürünler şunlardır; Ayaklı ve ayaksız ürünler, kapaklı bardaklar, kaseler, sürahiler, kristal cam eşyaları ve kandillerdir [30].

1860'l1 yıllara gelindiğinde ise, sanayi durma noktasına gelmiştir. Bu dönem birinci sanayileşme teşebbüsü dönemi olarak adlandırılmaktadır. 1860 yıllarda dönemin teknolojisini takip etmeyen ve yenilenmeyen fabrikalar (özel ve devlet) kapanmaya başlamıştır [28].

Osmanlı İmparatorluğu tüketiciyi ve üreticiyi koruyacak kararları ivedilikle almak için harekete geçmiştir. Bu sebeple 1863 yılında Islah-1 Sanayi Komisyonu kurulmuştur [1]. Komisyonun kurulmasındaki amaç, Osmanlı Devleti'nin sanayisini geliştirmek ve dışa bağımlılığını ortadan kaldırmaktır [31]. Islah-1 Sanayi Komisyonu'nun görevi, gümrük vergilerinin arttırılması, sanayi okullarının açılması, şirketlerin kurulması ve sergiler düzenlenmesi idi [27].

Şirketlerin kurulması için Osmanlı Devleti, esnafa yurtdışından temin edilecek hammaddede ve makineler için vergi alınmayacağını belirtmiştir. Ancak burada alınan kararlar uzun süreli olmamıştır ve Kapitülasyonlar sebebiyle hayata geçirilmemiştir. Komisyon 1872 y1lında kapatılmıştır [27]. Komisyonun amacına ulaşamamasının nedenleri, Osmanlı'nın dış borçlarını ödeyemez hale gelmesi ve lüks sayılabilecek harcamaların üst düzeye çıkmasıydı [32].

Batılı sanayileşmenin artışı ile Osmanlı Devleti'nde siyasi, toplumsal ve kültürel alanlarda çeşitli değişimler ve modernleşme çalışmaları yapılmıştır. Bu durum, İstanbul'un kentsel morfolojisini etkilemiştir [19].

Yeni bir Batılı hayat tarzına geçiş yapan Osmanlı Devleti'nde, 1857 yılında, İstanbul'da bulunan ve Pera, Galata, Tophane'yi kapsayan bir belediye kurumu (Altıncı Daire-i Belediye) kurulmuştur. Yeni kurulan bu belediye sayesinde Avrupa kentlerindeki düzenlemeler örnek alınmaya başlanmıştır [33]. 


\subsection{Cumhuriyet Dönemi İçerisinde Yapılan Düzenlemeler (1923-1940)}

Ülkenin, Cumhuriyet'in ilanından sonraki durumuna ekonomik olarak bakıldığında, Türkiye Cumhuriyeti'nin ilk on y1lı (1923-1933) ülkenin iktisat politikasında arayışların başladığı yıllar olarak belirtilmektedir [1].

Türkiye Cumhuriyeti'nin uygulanacak ekonomik politikasının tespit edilmesi amaciyla 17 Şubat- 04 Mart 1923 tarihleri arasında, 1135 delegenin de katılımıyla, İzmir'de İzmir İktisat Kongresi toplanmıştır [1]. 1923-1930 yılları arasında uygulanan enerji politikalarının ana hatları, 1923 yılında yapılan İzmir İktisat Kongresi'nde belirlenmiştir [34].

Ortaya çıkan iktisadi problemlerin çözümlerinin aranması ve bulunması amacıyla dönemin hükümeti tarafından kongrenin yapılmasına karar verilmişti. Kongre çatısı altında alınan kararlar iki başlık altında toplanmıştır. Bunlar;

1. Misakı İktisadı (İktisadi Antlaşma)

2. Sanayici, tüccar, çiftçi ve işçi gruplarına ilişkin esaslardır [35].

$\mathrm{Bu}$ iki başlık altında alınan kararların o dönem içerisinde ülkeyi kalkındırmaya yönelik çözümlerin olması hedeflenmiştir. Kararlardan, sanayi ile ilgili olanları, şunlar olmuştur [35], [36];

1. Ticaret ve Sanayi odaları kurulacaktır,

2. Yerli üretiminin geliştirilmesi için uğraşılacaktır,

3. Lüks ithalattan mümkün mertebe kaçınılması hedeflenecektir,

4. Yabancı sermayeye, ülkenin ekonomik gelişmesine katkıda bulunduğu sürece, izin verilecektir,

5. Teşvik-i Sanayi Kanunu endüstriyel gelişmeye katkı sağlayacak biçimde yeniden düzenlenecektir ve en az 25 sene süreyle yürürlükte kalacaktır,

6. Sanayi ve Sanayici teşvik edilecektir,

7. Sanayinin ve sanayicinin ihtiyaç duyduğu teknik elemanların yetiştirilmesi için elzem olan eğitim kurumları oluşturulacaktır. 
Teşvik-i Sanayi Kanunu: Osmanlı Devleti hükmünün sürdüğü 1913 yılında sanayiye katkı amacıyla Teşvik-i Sanayi Kanunu Muvakkati adıyla bir yasa çıkarılmıştır. Fakat ülkenin içinde bulunduğu kötü koşulları sebebiyle düzgün ve yararlı sonuçlar alınamamıştır. $\mathrm{Bu}$ dönem içerisinde rafa kaldırılan bu yasa, İzmir İktisat Kongresi'nde Teşvik-i Sanayi Kanunu adıyla yeniden gündeme gelmiştir. Buradaki amaç o dönem içerisindeki sanayi şartlarına uygun olarak yeniden düzenlenmesidir [37].

$\mathrm{Bu}$ yasanın önemli olmasının sebebi, ülkedeki sanayileşmeye katkı sağlayacak biçimde yazılmış olmasıdır. Ayrıca Atatürk ilkelerinden biri olan Devletçilik ilkesinin anlamını açıklamaktadır [1].

Teşvik-i Sanayi Kanununda, yerli yatırımcı korunurken ve yatırım yapması için çabalanırken, aynı zamanda yabancı yatırımcılar için de yatırıma özendirici çalışmalar yapılmıştır [1]. Yabancı yatırımcılardan ülkeye çeşitli ürün girişleri olması sağlanmıştır.

$\mathrm{Bu}$ durum kanun içerisinde öngörülemeyen sonuçlara da yol açmıştır. Ülkede geri kalmış olan sanayi kollarına destek vermesi düşünülen yatırımların yerine, yabancı yatırımcıya bağımlı hale gelinmiştir [38]. 1927 yılında kabul edilen bu kanun 15 sene boyunca aynı adla süregelmiştir ve 1942 yılında sonlandırılmıştır. [37]

Teşvik-i Sanayi Kanunu dönemi boyunca çeşitli sanayileşme girişimleri olmuş ve 1923-1930 yılları arasında ülkedeki sanayileşmenin ve sanayi kollarının durumunu ortaya çıkaracak bir sergi kurulması hedeflenmiştir. Milli İktisat ve Tasarruf Cemiyeti'nin 20 Nisan 1930’da kurulmasına önayak olduğu Milli Sanayi Numune Sergisi Ankara' da açılmıştır. [1].

Milli Sanayi Numune Sergisi’nde dönemin sanayi kolları olarak görülen mobilya, dokuma, oyuncak üretimi ve çeşitli dallardan ürünler sergilenmiştir [39]

Sergide yer alan sanayi ürünlerine bakıldığında, Türkiye Cumhuriyeti kurulmadan evvel Osmanlı Devleti'ndeki sanayi kollarının ürünleri sergilenmekteydi. Bu durum, Teşvik-i Sanayi Kanunu'nun desteği ve teşviklerinin ülkedeki sanayileşmeye yeterince nüfuz etmediği olarak yorumlanmaktadır [1]. 
Sergi kapsamında yer alan sanayi ürünleri içerisinde aydınlatma ürünleri ile ilgili bir kayda rastlanılmamıştır. Türkiye Cumhuriyeti kurulmadan evvel üretilmiş sanayi ürünlerinin sergilenmesi dolayısıyla, aydınlatma elemanlarına rastlanmaması, Osmanlı Devleti'nin aydınlatma ürünlerinde ithal ürünleri tercih ettiğinin bir göstergesi olarak algilanmaktadir.

\section{5. İstanbul'un Ticari Merkezleri}

Osmanlı Devleti'nin başkenti olan İstanbul şehri, dört idari bölgeye ayrılmıştır. Dersaadet ve Bilad-ı Selase (üç belde) olarak bilinen Galata, Eyüp ve Üsküdar bu dört adet bölgeyi oluşturmaktadır. Haliç'in karşı kıyısında bulunan Galata, Bizans döneminden itibaren İstanbul'da ikamet eden Cenevizli tüccarların yaşadığı bölge olarak bilinmekteydi. Galata'nın yukarısındaki bölgede ise Yunanca 'da "Altın boynuzun karşısında" anlamına gelen Pera yer almaktaydı. Aynı bölgeye Avrupalılar Pera derken, Türkler Beyoğlu olarak adlandırmıştır. Pera, İstanbul'da yaşayan batılı tüccarların, Avrupalı elçilerin, diplomatik görevlilerin ve onların ailelerinin yeni yaşam merkezi olmuştur [19].

Sahil ile Galata kulesi arasında kalan Pera bölgesi, 17. Yüzyılda Pera bağları adıyla anılmaktaydı. Bu bölge 19. Yüzyıla kadar daha az yoğunluklu bir bölge olarak bilinmekteydi. Ancak 19. Yüzy1l itibariyle Levantenlerin yerleştiği bir bölge olarak nam salmıştır. Levantenlerin haricinde yerli gayrimüslim ve Türk vatandaşlar bu bölgede toplanmışlardır. İlerleyen senelerde Pera Galata’nın bir uzantısı olarak anılmamış, farklı kültürden gruplara ev sahipliği yapmıştır. Bu gruplar içerisinde İtalyan, Maltalı, Ermeni, Yahudi, Katolik ve Ortodoks Rumlar yer almaktadır. Bu grupların içerisinde Müslüman kesimin sayısı azınlıkta kalmıştır. Bu bölgede ikamet eden Müslümanlar ise İslam dinini sonradan kabul eden Batı kökenli bireylerdir [14].

Derin Öncel [13], Galata ve Pera bölgesinde ikamet eden kişilerin bir kısmının ticaretle uğraşan tüccar grubuna mensup olduğunu 
belirtmiştir. İnalcık ise [40] 18. Yüzyıldan itibaren Galata'da ticaretin ağırlıklı olarak gayrimüslimlerin ve Levantenlerin elinde olduğunu belirtmiştir. Türklerin gıda ticareti ile uğraştığını, Rumların ise ithal malların alım ve dağıtımlarından sorumlu olduğunu ifade etmiştir. $\mathrm{Bu}$ kişiler bu bölgenin eski sakinleridir. Ancak zaman içerisinde zenginleşerek yeni binalar inşa etmişlerdir. Bu binalar içerisinde konut alanları ve ticarethanelerin birlikte yer aldığı varsayılmaktadır. Bu bölge içerisinde yer alan ama bölgenin eski sahiplerine mensup olmayan bir diğer grup ise; bu bölgede daha iyi iş yapabilmek veya çalıştığı ticarethaneye yakın olabilmek için yerleşen gruptur [13].

1840'l y yllardan itibaren İstanbul'un geçirdiği sosyal, iktisadi ve yeni yapılanmalar eşliğindeki değişimler sonucunda toplumsal merkezi iş alanı kavramı farklılaşmıştır. Farklılaşma ile İstanbul'un merkezi iş alanı yeniden tanımlanmıştır. Ticaretin geliştiği ve değiştiği İstanbul'da mekânların farklılaşması ile yeni iş merkezi alanlarının gelişmesi, dönemin ekonomik ilişkilerinin mekânlara yansıması olarak ortaya çıkmıştır. İstanbul'a gelen mal girişlerinin artışı ile yeni depolara ve indirme/bekleme/saklama alanlarına ihtiyaç duyulmuştur. Depoların inşa edilmesi sonucunda mal girişleri artmış ve İstanbul tüccarların yoğun olarak geldiği bir şehre dönüşmüştür [41].

19. yüzyılın ikinci yarısından itibaren Beyoğlu'nun nüfusunun artması ile konut ihtiyacı ortaya çıkmıştır. Bu ihtiyaca cevap verebilmek adına yerli veya yabancı usta ve mimarlar yeni yerleşim alanlarının yapımını üstlenmişlerdir [13]. Bu sebeple İstanbul' da kalmak isteyen tüccarlar için yeni oteller ve iş hanları inşa edilmeye başlanmıştır. Otellerin inşası için ticaretin ve depoların yoğunlaştığ 1 alan olarak, dönemin ticaret merkezi Eminönü, Beyazıd ve Unkapanı'nın karşı k1yısında yer alan Karaköy, Galata ve Bankalar Caddesi uygun bölge olarak belirlenmiştir. Burada yer alan iş hanları geleneksel Osmanlı hanlarından farklı olarak, bürolar şeklinde şekillenmiştir. Avrupa'dan ithal lüks tüketim malları satan dükkanlar ve çeşitli kamusal alanlar, iş hanlarından ve otellerden etkilenerek Pera bölgesine yerleşmişlerdir. Pera bölgesi başlangıçta yabancı elçiliklerin bulunduğu bölge olarak 
bilinmektedir. Dükkanların, otellerin, iş hanlarının ve kamusal alanların bu merkez etrafinda yoğunlaşması ile sadece tüketen bir toplum olmaktan çıkmış ve ithalat ile ihracatın da yapılmaya başlandığg yeni bir döneme geçme adımları atılmıştır [41].

Galata ve çevresinde Avrupai üslup ile ticari binalar ve bankalar yapılmıştır. Yeni yapılaşmalar ile şehrin ekonomik merkezi Galata ve çevresine doğru kaymıştır. 1840 yılından sonra Galata ve Pera İstanbul'da Avrupai ürünlerin satıldığı dükkanlara, eğlence yerlerine, otellere ve okullara ev sahipliği yapmaya başlamıştır [19].

Galata bölgesinin ticaret ağırlıklı bir bölgeye dönüşmesi ile özellikle Voyvoda Caddesi üzerinde yoğunlaşan hanlar, depolar, dükkanlar, büro ve ticarethaneler yer almaya başlamıştır. Ayrıca ekonominin bu denli yoğun olduğu bölgede borsa, bankalar ve bankerler konuşlanmıştır [14].

İstanbul'da değişen merkezi iş alanı kavramı ile eski ve yeni merkezler, bölge olarak, karşı karşıya gelmiştir. Bu iki ayrı merkez yeni olan ile (ticaretin yoğunlaşması, tüccarların şehre gelişleri ile ithalatın artışı) eski olanı (geleneksel esnaf ve zanaatkarlık) karşı karşıya getirmemiş, bilakis uyum içerisinde, ikili bir yapı kurarak var olmaya devam etmişlerdir. Yeni fonksiyon tanımları ile Beyoğlu ve Galata bölgesi ticari açıdan yabancı ve gayrimüslim tüccarların yoğun ilgisi altında kalmıştır [41].

1853-1856 yılları arasında yapılan Kırım Savaşı sonrasında, halkın ekonomik olarak yaşadığ 1 sıkıntıların ilerleyen yıllarda devam etmesini firsat olarak gören Galatalı tüccarlar, iş adamları ve bankerler nüfuzlarını arttırmak amaçlı atılımlarda bulunmuşlardır. Galata' da yer alan banker ve tüccarların sahip oldukları varlıklar ile Grande Rue de Pera boyunca binalar ve yeni tip alışveriş alanları yaptırılmıştır. Açılan yeni dükkanlar ile ithal Avrupai mallar satılmaya başlanmıştır. Yeni tip Avrupa mallarına rağbet eden kesim sadece Avrupalılar ve Levantenler değildi, Müslüman bürokratlar ve üst düzey memurlar da buralardan alışverişlerini yapmaktaydılar. Burada yer alan dükkanlara ek olarak Pera' da yeni anlayışlarla kurulan oteller ve eğlence hayatı, bu bölgede Batı tarzının yeni kimliğini ortaya çıkarmıştır [19]. 
Galata'da yapılan ticaretin, kentsel boyuttaki yerleşim planına etkisi büyük olmuştur. Ancak bu bölge içerisinde belirli kişiler ve kurumlar yer almaktaydı. Örneğin Karaköy-Perşembe Pazarı hattında fabrikalar ve imalathaneler bulunmaktayd. Voyvoda Caddesinde Osmanlı Bankası vb. büyük bankalar ve sigorta şirketleri bulunurken, Karaköy'den itibaren Beyoğlu'nu kapsayan aksta lüks mağazalar konuşlanmıştı. Eski zanaat bölgesi olan ve genellikle Türk vatandaşların tercih ettiği Sirkeci- Eminönü hattında ise toptan- perakende satış ve üretim faaliyetlerinin yer aldığ hanlar ve ticari merkezler bulunmaktayd1 [42].

Alışveriş ağının yoğun ve popüler olduğu Pera Caddesi üzerinde yer alan yeni yapılar çok katlıdır ve binaların alt katlarında büyük mağazaların, dükkanların ve hatta pasajların yer aldığ 1 görülmektedir [14]. Şekil 2.'de görüldüğü üzere dönemin büyük mağazalarından biri olan Au Bon Marche'nin yer aldığ1 Batılı tarzda bir yapı bulunmaktadır. Ancak 1870 yılında yaşanan büyük Pera yangınlarında Bon Marche mağazası dahil dört bine yakın yapının yandığ 1 ve buna ahşap yapılar ile taş konutların da dahil olduğu belirtilmiştir. Bu yangınlar doğrultusunda Pera'nın Taksim-Galatasaray aksında büyük fiziki değişimler yaşanmıştır [14].

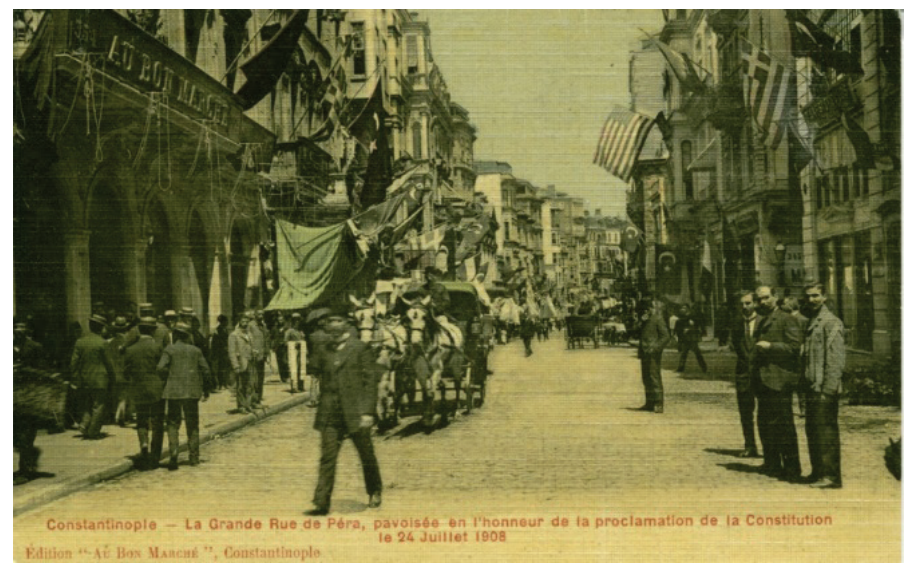

Şekil 2. İBB Atatürk Kitaplığı. Beyoğlu- Grande Rue Péra'da (Cadde-i Kebir /İstiklal Caddesi) yer alan Au Bon Marché mağazası [43] 


\subsection{Basılı Yayınlar Üzerinden Zanaatkar ve Tüccarın İzini Sürmek}

Çalışmanın bu bölümünde, aydınlatma üretici ve tüccarlarının izleri takip edilmeye çalışılacaktır. Bu bilgileri toplamak için ise düzenli olarak yayınlanan ticaret yıllıklarından yararlanılacaktır. Bu yıllıklar içerisinde yer alan ilgili başlıklarda; üretici ve tüccarların isimleri, ticareti yaptıkları dükkanların adresleri ve numaraları yer almaktadır. $\mathrm{Bu}$ y1llıklar içerisinde yer alan üretici ve tüccarların meslek bilgileri ve adresleri dışında herhangi bir bilgi bulunmamaktadır.

Şam Rehberi (Le Guide Sam), 1922 yılından 1930 y1lına kadar Akdeniz havzası içerisinde yer alan ülkelerin bilgilerini ve işletmelerinin adreslerini listeleyen bir yıllıktır. Şam Rehberi, Sam Lévy tarafından yayınlanmıştır ve tam ismi Annuaire De L'Orient, Le Guide Sam (Doğu Y1llığı, Şam Rehberi) olarak geçmektedir. Bu rehber içerisinde yer alan ülkeler; Fransa, İtalya, Türkiye, Misır, Yunanistan, Bulgaristan ve Filistin olarak belirtilmiştir. Şark Ticaret Yıllıklarında olduğu gibi içerisinde; işletmeler, işletmelerin adres bilgileri ve çeşitli reklamlar yer almaktadır. Her ülke için ayrıca bilgilendirme yazıları da bulunmaktadir.

Annuaire Oriental- Şark Ticaret Y1llıkları 1868-1945 yılları arasında hazırlanmıştır. İstanbul'un eski ve yeni iş merkezleri üzerinden iktisadi faaliyetleri ve meslek yapılarını ortaya çıkarma ve bilgilendirme amaçlı yayınlanmıştır. İstanbul'daki iktisadi faaliyetler ile meslek yapılarının ortaya çıkarılmaya çalışıldı̆̆ı, ekonomik olarak farklı katmanlar üzerinden genellemeler yapılmasını takip etmeye yönelik yayınlar olarak ele alınmaktadır Annuaire Oriental- Şark Ticaret Yıllıkları olarak adlandırılan bu yıllıkların asıl amacı, Osmanlı Devleti içerisinde yer alan ticari merkezleri yerel ve yabancı girişimcilere tanıtmaktır. [41]. Yıllıkların basım dili Fransızcadır. Cumhuriyetin ilanından sonra ise yayınlar Türkçe ve Fransızca olarak basılmıştır.

Y1llkların yayınlanmasındaki amaç, Dünya üzerinde herhangi bir ticari limandan binip İstanbul-Galata rıhtımında inen bir tüccarın 
ihtiyaç duyduğu tüm ticari bilgilere ulaşabilmesidir. Tüccarın ilgi alanındaki malın kim tarafından üretildiğini veya o malı ithal eden temsilcinin kim olduğunu öğrenmek amacıyla Şark Ticaret Yıllıklarının yayımlandığı düşünülmektedir [41].

Şark Ticaret yıllıklarında İstanbul'un geleneksel (Eminönü, Beyazıd, Kapalıçarşı) ${ }^{1}$ ve yeni (Galata, Pera) ticari alanları cadde ve sokak olarak detaylıca ele alınmıştır. Cadde ve sokakların çalışma merkezleri, faaliyet alanları ve şirket sahipleri ismen alfabetik olarak sıralanmıştır. Ayrıca iş alanlarının bulunduğu caddeler ve sokaklar ayrılarak, şirket sahiplerinde olduğu gibi, alfabetik şekilde listelenmiştir.

Aktar [41]; tüketim malı satan tüccarların, Tanzimat dönemi sonrası İstanbul' da yaşayan ve ilk olarak üst düzey alım gücüne sahip, daha sonra orta tabaka olarak tabir ettiği grubun alım gücünün değişimini ve genişlemesini yıllar içindeki ithalatçıların çeşitlenip uzmanlaşmasından anlaşılabileceğini belirtmiştir. Aydınlatma işi ile ilgilenen tüccarların ve üreticilerin yıllar içerisinde Şark Ticaret Yıllıklarına verdikleri ilanların başlıklarının değişimlerinden uzmanlık alanlarının farklılaştığı anlaşılabilmektedir. Örneğin Şark Ticaret yıllığında yer alan Chandeliers (marchands de) başlığı, ilerleyen yıllarda kaldırılmıştır. Aydınlatma ile ilgili başlıklar, yıllıkların yayınlandığ 1 ilk dönemlerde detaylandırılarak incelenmiş ancak sonraki yıllarda toplu olarak tek başlık altına indirgenmiştir. Bu durum, üretici-tüccar-komisyoncu-simsar grubunun kendi içerisinde uzmanlaşmaya doğru gittiği ve ülkeyi ticari amaçlı ziyaret eden tüccarların ilgilendiği ürünlerin bu yıllıklar içerisinde tek bir başlık altında kolay bulabilmeleri adına atılmış bir adım olarak değerlendirilmiştir.

Yağız ve Ağır [44]; yabancı tüketici ürünlerinin İstanbul pazarında bulunmasının sebeplerinden birini, yabancı üreticilerin ticari temsilciliğini yapan komisyoncular olmasına bağlamışlardır. Burada satışa sunulan ürünlerin çok katlı mağazalarda veya komisyoncu/tüccarların

1 İstanbul'un eski ticari bölgeleri olan Eminönü, Kapalıçarşı ve Beyazıd bölgeleri çalışma içerisinde Stamboul olarak belirtilmiştir. 
kendi dükkanlarında satışa sunduklarını belirtmişlerdir. Bazı büyük ve yabancı firmalar, bizzat kendilerinin açtıkları mağazalarda ürünlerinin satışını gerçekleştirmişlerdir. Çoğunluğu Pera'da yer alan bu mağazalar, ithal ve yerli mallar ile çeşitli tüketim ürününü bir arada sunarak, halka satışı kolaylaştırmıştır.

Şark Ticaret Yıllıkları içerisinde yer alan ve aydınlatma üretici ile tüccarlarının sıralandığı başlıklar altında yapılan belgesel tarama ile bir kronoloji oluşturulmuştur. Bu kronoloji dahilinde 1880-1930 y1lları içerisinde yıllıklara eklenen üretici ve tüccarlar sıralanmıştır. Kronolojiyi oluşturabilmek için Şark Ticaret Yıllıklarının ve Şam Rehberlerinin bulunabilen basımlarından yararlanılmıştır.

Bu basımlar içerisinde aydınlatma üretici ve tüccarlarının ilan verdiği çeşitli başlıklar taranmıştır. 1880 yılından 1930 yılına kadar geçen süreçte değişikler yaşandığı görülmüştür. 1880 yılından itibaren Şark Ticaret Yıllıkları içerisinde yer alan ve aydınlatma aygıtı satışı yapan işletmelerin verdiği ilanların başlıkları özelden genele doğru gitmiştir. Örneğin 1880 yılında Türk tipi fener üretici ve tüccarı ile avize ve şamdan tüccarı kişilerin olduğu belirtilmiştir. İlerleyen yıllarda, detaylandırılan başlıklar yerini genel başlıklara bırakmıştır.

Şam Rehberlerinde ise İstanbul içerisinde yer alan işletmelerin bulunduğu başlıklar, İstanbul'daki faydalı adresler başlığı altında derlenmiştir. Buradaki işletmeler, Şark Ticaret Yıllıklarında olduğu gibi kapsamlı değildir. Ancak genel başlıklar altında sıralanmışlardır. Aydınlatma elemanları satış ve üretimini yapan kişilerin taranması için ulaşılabilen tek başlık Electricité başlığı olmuştur.

İncelenen başlıklar ve başlıklar altında ilan veren işletmelerin sayıları Tablo 1.'de belirtilmiştir. 
Tablo 1. Şark Ticaret Yıllıklarında ve Şam Rehberlerinde aydınlatma ile ilgili aranılan başlıklar içerisinde toplam ilan sayısı (1880-1930)

\begin{tabular}{l|l}
$\begin{array}{l}\text { Şark Ticaret Yıllıkları ve Şam Rehberleri İçerisinde Yer Alan } \\
\text { Başlıklar }\end{array}$ & İlan Sayısı \\
\hline Appareils d'éclairage & 193 \\
\hline Chandeliers (Merchands de) & 16 \\
\hline Chandeliers Plateaux et antres articles en Cuivre Jaune (March ds de & 95 \\
\hline Eclairage & 1 \\
\hline Eclairage au gazolyt & 1 \\
\hline Electriciens & 399 \\
\hline Electricité & 305 \\
\hline Laiton (Marchands de plateaux et de chandeliers en) & 2 \\
\hline Lampes (march. De) & 314 \\
\hline Lampes a Pétrole (Import de) & 11 \\
\hline Lampes et Lustres (Marchands de) & 4 \\
\hline Lampistes & 73 \\
\hline Lanternes (Marchands de) & 2 \\
\hline Lanternes Pour Bateaux (Fabric. De) & 2 \\
\hline Lanternes Turques (Fabts et Marcds) & 13 \\
\hline Lumiére & 7 \\
\hline Lustres & 32 \\
\hline Lustres En Cristal & 22
\end{tabular}

Şark Ticaret Y1llıklarında 1880-1930 y1lları arasında toplam 26 adet y1llık taranırken, Şam Rehberlerinde 1922-1930 yılları arasında toplam 9 adet yıllık taranmıştır. Bu yıllıklar içerisinde Şark Ticaret Y1lliklarında toplam 1320 adet ilan verilirken, Şam Rehberlerinde ise toplam ilan sayısının 172 adet olduğu tespit edilmiştir. 1880-1930 yılları arasında Fransızca basım yapan iki farklı ticaret yıllığ 1 içerisinde toplam ilan sayısının 1492 olduğu belirlenmiştir. 
Şark Ticaret Yıllığg bünyesinde ilan veren işletmelerin sayısı ise 516 adet iken, Şam Rehberlerinde ilan veren toplam işletme sayısının 38 olduğu tespit edilmiştir.

$\mathrm{Bu}$ yıllıklar içerisinde yalnızca elektrikli aydınlatma ile aydınlatma elemanları satış ve üretimi ile ilgilenen işletmeler yer almıştır. İlan verilen başlıklar yıllar içerisinde çeşitli değişimler geçirmiştir. Ancak 1929 yılı itibariyle başlıklardaki uzmanlık alanları azaltılmış ve 1930 yılında sadece elektrik ile ilgili olan başlıklar kalmıştır. Aydınlatma ile ilgili olan başlıklar belirli bir sınıflandırma ile sadeleştirilmiştir.

Şark Ticaret Yıllıkları içerisinde en çok Electriciens başlı̆̆ altında işletmenin yer aldığı görülmektedir. 1895 sonrası ilana açılan bu başlık, 1930 yılına kadar popülerliğini iyice arttırmıştır. Ardından Lampes (march. De) başlı̆̆ ilana açılmıştır ancak bu başlık 1880-1909 yılları arasında aktif olmuştur. Lampes başlığına en son 1909 yılında ilan verilmiştir. 1909 yılından itibaren Lampes başlığı altında verilmek istenen ilanlar Appareils d'éclairage başlıklarına taşınmıştır. Bu sebeple Lampes başlığından sonra en çok ilan verilen başlık Appareils d'éclairage başlı̆̆ı olmuştur.

Şark Ticaret Y1llıkları yıl bazında değerlendirildiğinde ilan veren kişilerin yıllar içerisinde artış eğiliminde olduğu görülmektedir. Ancak bu durum her sene yeni bir işletme kurulmuş olarak değerlendirilmemelidir. Aydınlatma elemanlarının üretim ve satışında çalışan ve dükkan sahibi olan işletme sahiplerinin bahsi geçen yıllıklara, düzenli ilan vermeyi tercih etmemeleri olasılık dahilindedir. Bu sebeple, yıllıklara ilk kez ilan veren işletme sahiplerinin kuruluş yılları ile ilgili kesin bir değerlendirmede bulunmak doğru bir yaklaşım olmayacaktır.

\subsection{Aydınlatma Ürünlerini Dergi ve Gazete Reklamları ile Takip Etmek}

TDK'ya [45] göre reklam; "bir şeyi halka tanıtmak, beğendirmek ve böylelikle sürümünü sağlamak için denenen her türlü yol” ve "bu amaç 
için kullanılan yazı, resim, film vb.” olarak belirtilmiştir. Buna göre, TDK'nın [45] tanım olarak belirttiği üzere reklam; bir şeyin halka tanıtılması ve gösterilmesi için yazılı ve görsel kaynaklar kullanılarak pazarlanması olarak tanımlanabilir.

18. yüzyılın sonlarına doğru Osmanlı Devleti'nde, ilan şeklinde verilen reklamlar çıkmıştır. Bu reklamlarda sadece yazı kullanılmıştır. Bunun sebebi, İslam inancının yoğun olduğu Osmanlı Devleti'nde resimli ürün tanıtımlarının tepki ile karşılanacağı düşüncesi olmuştur [46]. 1880 yılından itibaren sadece yazılı reklamlar, yerini resimli reklamlara bırakmaya başlamıştır. II. Abdülhamit döneminde reklamlar, içerik itibari ile Avrupa'da yayın yapan dergi ve gazeteler ile yarışır hale gelmiştir. Ancak ilerleyen senelerde Osmanlı Devleti'nin girdiği savaşlar ve ekonomik darboğazlar sebebi ile reklamcılık alanı sekteye uğramıştır [47].

İthalatın artması ve büyük mağazaların popülerleşmesi ile reklam ve tanıtımlar gazete ve dergilerde yaygınca görülmeye başlanmıştır. Ürün çeşitliliği, ithal edilen ürünün menşei ve kalitesi reklamlar içerisinde sıklıkla vurgulanmıştır. Ayrıca pazara yeni giren ürünlerin tanıtımları ve tutunmasına yönelik hareketler için sıklıkla reklamlardan destek alınmıştır [48].

Aydınlatma alanında dergilere reklam veren afişlerin bir dönemin aydınlatma elemanları tasarımlarına 1şık tutması hedeflenmektedir.

İncelenen yayınlardan biri Ameli Elektrik dergisidir. Elektrik ile ilgili okur-yazarlığı artırmak, kullanımına dair bilgiler vermek ve elektrikli aletlerin kullanımını teşvik etmek amacıyla İstanbul Elektrik ve Tramvay Şirketleri Ameli Elektrik adında bir dergi çıkarma teşebbüsünde bulunmuşlardır. Ameli Elektrik dergisi, para ile satışı olmayan yalnızca elektrik abonelerine özel olarak dağıtımı yapılan bir dergi statüsündedir [49]. Ameli Elektrik dergisi abonelere doğrudan posta yolu gönderimi yapılan ilk yaygın süreli yayın olma özelliğini taşımaktadır. Ameli Elektrik dergisi 1924-1936 yılları arasında basılmıştır. İlk zamanlarda her ay basılmış, ardından iki ayda bir yayınlanarak dağıtımı yapılmıştır. 1932 yılında 42.500 adet basılarak abonelere doğrudan yollanmıştır [33]. 
Ameli Elektrik dergisine reklam veren işletmelerden biri Satie firmasıdır. Satie firmasının verdiği reklamlar Şekil 3., Şekil 4., Şekil 5., Şekil 6.'da görülmektedir.

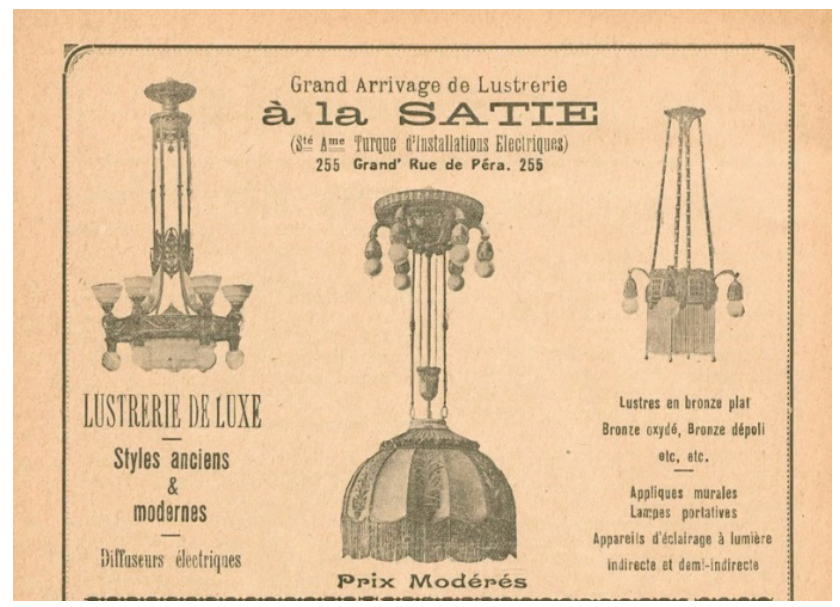

Şekil 3. Satie firmasının 1926 yılında Ameli Elektrik dergisine verdiği ilan [50]
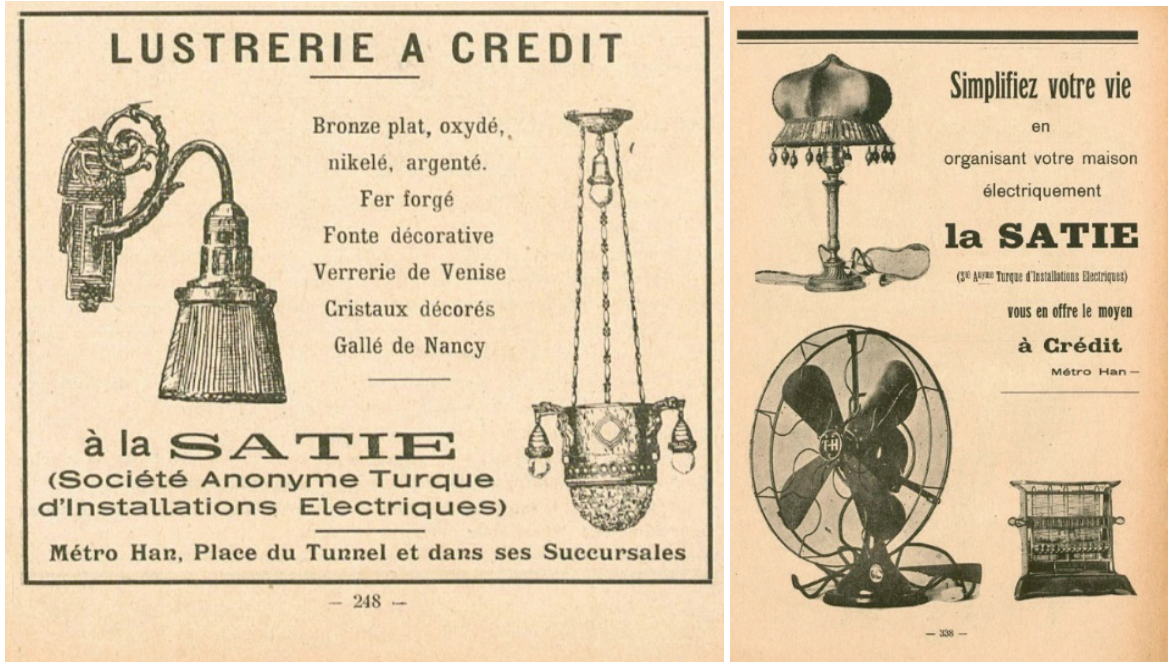

Şekil 4. Satie işletmesine ait afiş örnekleri [50] 


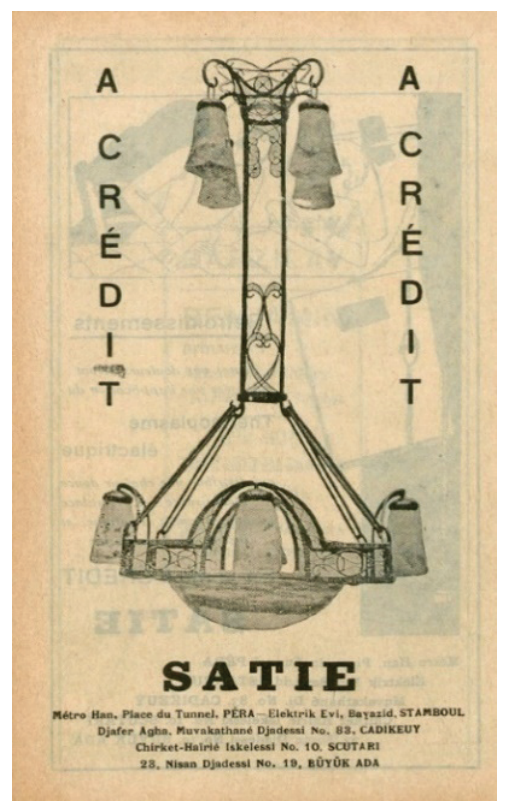

Şekil 5. Satie firmasının 1931 yılında verdiği tam sayfa reklam afişi [50]

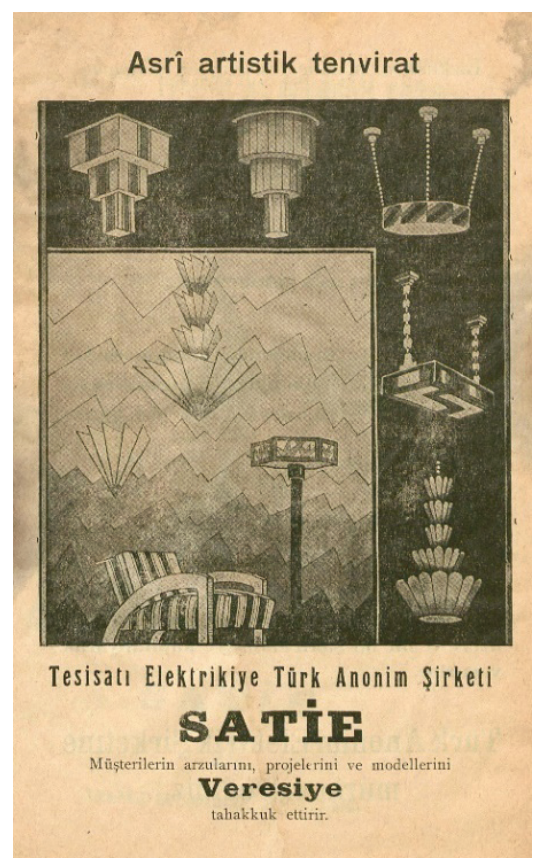

Şekil 6. Satie firmasının 1932 yılında verdiği tam sayfa reklam afişi [51] 
Fransizca yazılan "Société Anonyme Turque d'Installations Electriques" firmasının kısaltılmış versiyonu olarak tanınıp bilinen Satie firmasının Türkçe'de karşılığı "Tesisatı Elektrikiye Türk Anonim Şirketi” olarak geçmektedir [51]. İlanda, Satie firmasının Fransızca yazılmış olan uzun ve kısa isimleri birlikte kullanılmaktadır.

Ameli Elektrik dergisinde Satie firmasının verdiği ilanda, veresiye ile lamba satışı yapıldığı belirtilmiştir. Lüks ve statü göstergesi olan aydınlatma elemanına ulaşma çabası içerisinde olan bir tüketici, Satie firması sayesinde bu ürüne veresiye ile sahip olabileceğini ilan vasitasıly görmektedir. Satie firmas1 1920'li yıllardan itibaren veresiye satış ile aydınlatma ürünü satışını yaygınlaştırmayı hedeflediği düşünülmektedir. Bu sayede pazarda bir rekabetin doğması ve aydınlatma ürünü satan firmaların çeşitlenmesi ve yaygınlaşmasına yön verdiği söylenebilmektedir.

\subsection{Haritalama Yöntemi ile Zanaatkar ve Tüccarın İzini Sürmek}

Yıllıklarda ve rehberlerde ilan veren zanaatkar ve tüccarların izini sürebilmek için haritalardan yardım alınmıştır. Çalışma alanı belirlenirken, Şark Ticaret Yıllıkları ve Şam Rehberinde ilan vermiş kişiler Charles Eduard Goad tarafindan hazırlanan sigorta haritaları kullanılmıştır. İşletmeler, Goad haritası üzerinde işlenerek bulundukları bölgelerde yoğunluk haritası oluşturulmak istenmiştir.

Y1llıklar dahilinde incelenen 1880-1930 yılları arasında altyapıda, çeşitli değişim ve dönüşümler yaşanmıştır. Sokaklar genişlemiş, farklılaşmış ve çoğaltılmıştır. Her yeni yayınlanan yıllık ile lambacılardaki artışlar bu değişim dahilinde değerlendirilmesi gerekmektedir.

Sanayi devriminin etkisi ile açık pazar haline gelen Osmanlı Devleti üzerinde yabancı devletlerden gelen çeşitli baskılar bulunmaktaydı. Osmanlı Devleti'nin ekonomik yönden yaşadığı sıkıntılar ile dış ilişkilerinde farklı bir evreye geçmiştir. Yabancı tüccarların ülkeye girişinin önü açılması ve vergi serbestisi ile yeni bir ticari anlayış başlamıştır. Yabancı tüccarlara ek olarak Osmanlı' da yaşayan azınlıkların 
da hızla gelişen ithalat üzerinde çeşitli baskılar kurmuş ve komisyon ile pazarlama üzerinde yoğunlaşmışlardır. Bu yeni tüccar sınıfı Galata' da konumlanmış olan finans gücünü de arkalarına alarak Galata' da yeni bir ticari merkez oluşturmuştur. Bu merkez, 1831 yılındaki Galata yangını ve 1864 yılında Galata surlarının yıkılması ile tüccar sın1fina en uygun boş alanı sunmuştur [4].

İstanbul, tarihi (geleneksel) ticaret bölgesi (Stamboul) üç bölgeye ayrılmaktadır. Birinci bölge, liman bölgesidir. Liman bölgesi ticari yönden kentin konumunu belirlemektedir. İkinci bölge, liman bölgesinden itibaren süregelen ve bölgenin güney yönüne doğru ilerleyen hanlar bölgesidir. Üçüncü bölge ise Nuruosmaniye ve Beyazıt arasında yerleşik halde konumlanan Kapalıçarşı' dır [4].

Ancak Galata modern ticari merkez olarak konumlanmıştır. Galata ve Pera'nın gelişmesiyle beraber büyük ticari merkezler ve alışveriş merkezlerinin odak noktası olmuştur. Ancak tüccarların büyük bir kısmı, Galata ve Pera'nın gelişmesine rağmen, Stamboul bölgesinde ticaret yapmaya devam etmişlerdir. Uzun Çarşı ve Mahmud Paşa caddeleri ile çevre bölgeler ana ticaret bölgeleri olarak tercih edilmekteydi. Stamboul bölgesinin gelişen Pera ve Galata'ya oranla tarihi geçmişi, işlevselliği ve kentsel dokunun etkisi ile cazibe merkezi olmayı sürdürmekteydi. Ancak Galata'ya geçişi kolaylaştıran köprü ve finans merkezinin bu bölgeye kayması ile Galata, 19. Yüzyılın ikinci yarısı itibariyle cazibe merkezi olmuştur. [52].

İşletmeler harita üzerinde işlenirken cadde, sokak ve hanlar içerisinde yer alan ticari şirketlerin yoğunlukları çeşitli renkler ile gösterilmesi hedeflenmiştir. Bu duruma göre;

1. 1-5 adet işletmenin yoğunlaştığ 1 cadde, sokak ve hanlar açık mavi,

2. 5-10 adet işletmenin yoğunlaştığ cadde, sokak ve hanlar koyu mavi,

3. 10-15 adet işletmenin yoğunlaştığı cadde, sokak ve hanlar sarı,

4. 15-20 adet işletmenin yoğunlaştığ cadde, sokak ve hanlar turuncu, 
5. 20-25 adet işletmenin yoğunlaştığı cadde, sokak ve hanlar kırmiz1,

6. 25-30 adet işletmenin yoğunlaştığı cadde, sokak ve hanlar bordo renkler ile gösterilmiştir.

İşletmelerin harita üzerinde işlenebilmesi için 10'ar yıllık tablolar oluşturulmuştur. Bu tablolar içerisinde;

1. İşletmenin yer aldığ 1 cadde, sokak veya han ismi,

2. İşletmenin ad1,

3. İşletmenin rehber ve yıllıklarda ilan verdiği yıllar,

4. İşletmelerin ilan verdikleri toplam sayılar yer almaktadır.

Charles Goad'un sigorta planları incelendiği zaman numara ve sokak isimlerinde farklılıklar olduğu görülmektedir. Harita planlarının yapıldığ 1 dönem itibari ile henüz yerleşmemiş isimlendirme ve numaralandırma sistemi olduğu göze çarpmaktadır [53]. Bu sebeple yoğunluk haritası oluşturulurken bu farklılıklar ele alınarak bir kümelenme oluşturulmuştur.

Şark Ticaret Y1llıklarından derlenen adresler üzerinden yapılan ve 1880-1890 yıllarına ait haritalamada; aydınlatma ile ilgilenen işletmelerin, İstanbul'un geleneksel üretim bölgesi olan Stamboul'da ağırlıklı olarak yer aldıkları belirlenmiştir. Bu bölge, Galata ve Pera bölgesine oranla işletmelerin daha fazla yoğunlaştıkları bölge olmuştur. Bu sebeple, Galata ve Pera bölgesinin ise Stamboul bölgesine oranla, ticari açıdan yeni gelişmeye başladığ 1 söylenebilmektedir. Bu gelişim Şekil 8 'de görülmektedir.

1880-1890 yılları arasında toplam 87 işletme ilan vermiştir. 


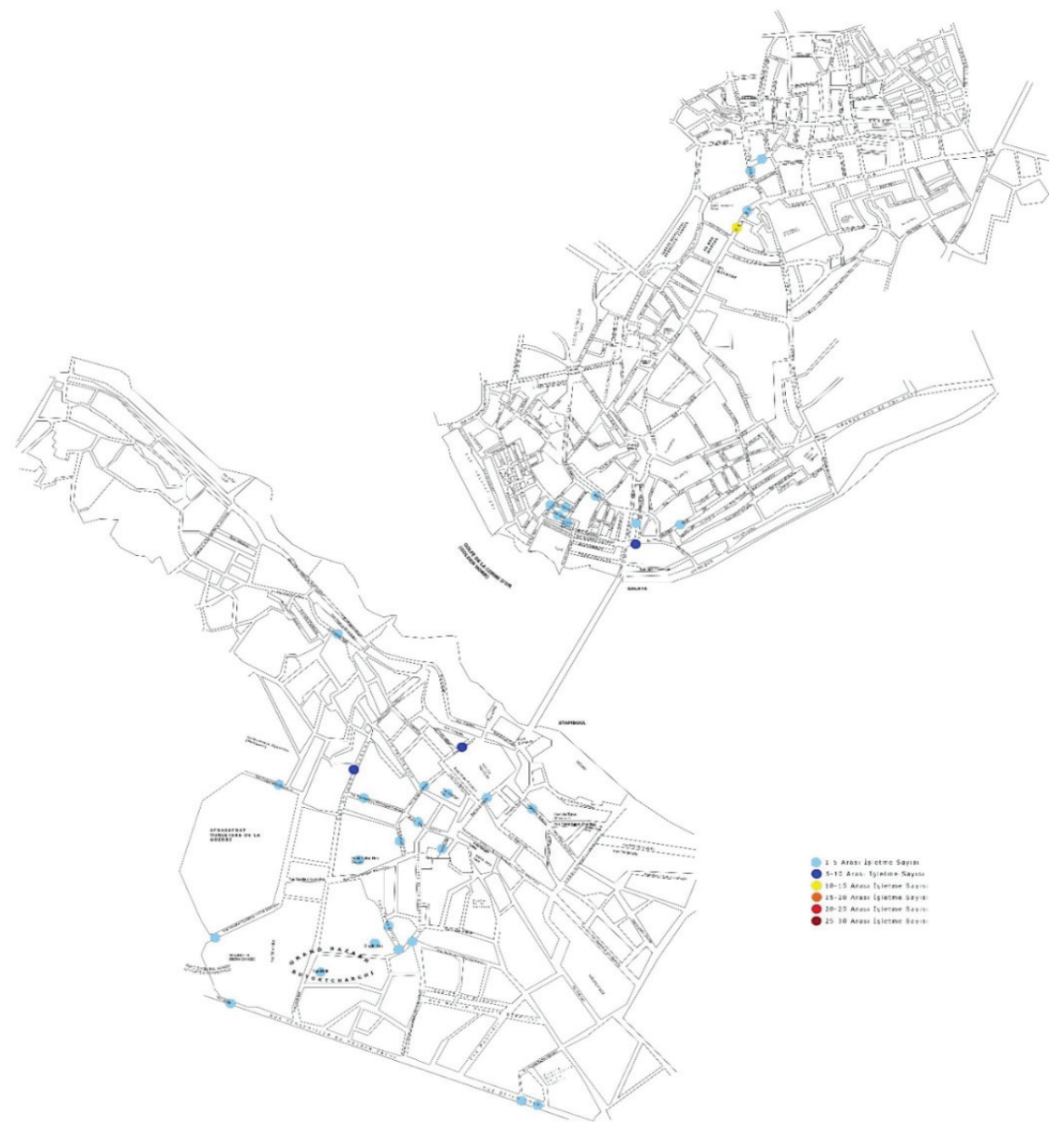

Şekil 8. 1880-1890 yılları arasında Şark Ticaret Yıllıklarına ilan veren işletmelerin yerleşimi (Yazar Zeynep FIRAT EZENCİ tarafindan oluşturulmuştur.)

1880-1890 yılları arasındaki yoğunluk haritasında Galata ve Pera bölgesine oranla Stamboul bölgesinde daha fazla işletmenin kaydı olduğu belirlenmiştir. Ancak 1892/1893-1900 yılları arasında Stamboul bölgesindeki yoğunluğun bir kısmının, Galata ve Pera’ya doğru kaydığı tespit edilmiştir. Bu harita Şekil 9'da görülmektedir.

1892/1893-1900 yılları arasında toplam 89 işletme ilan vermiştir. 


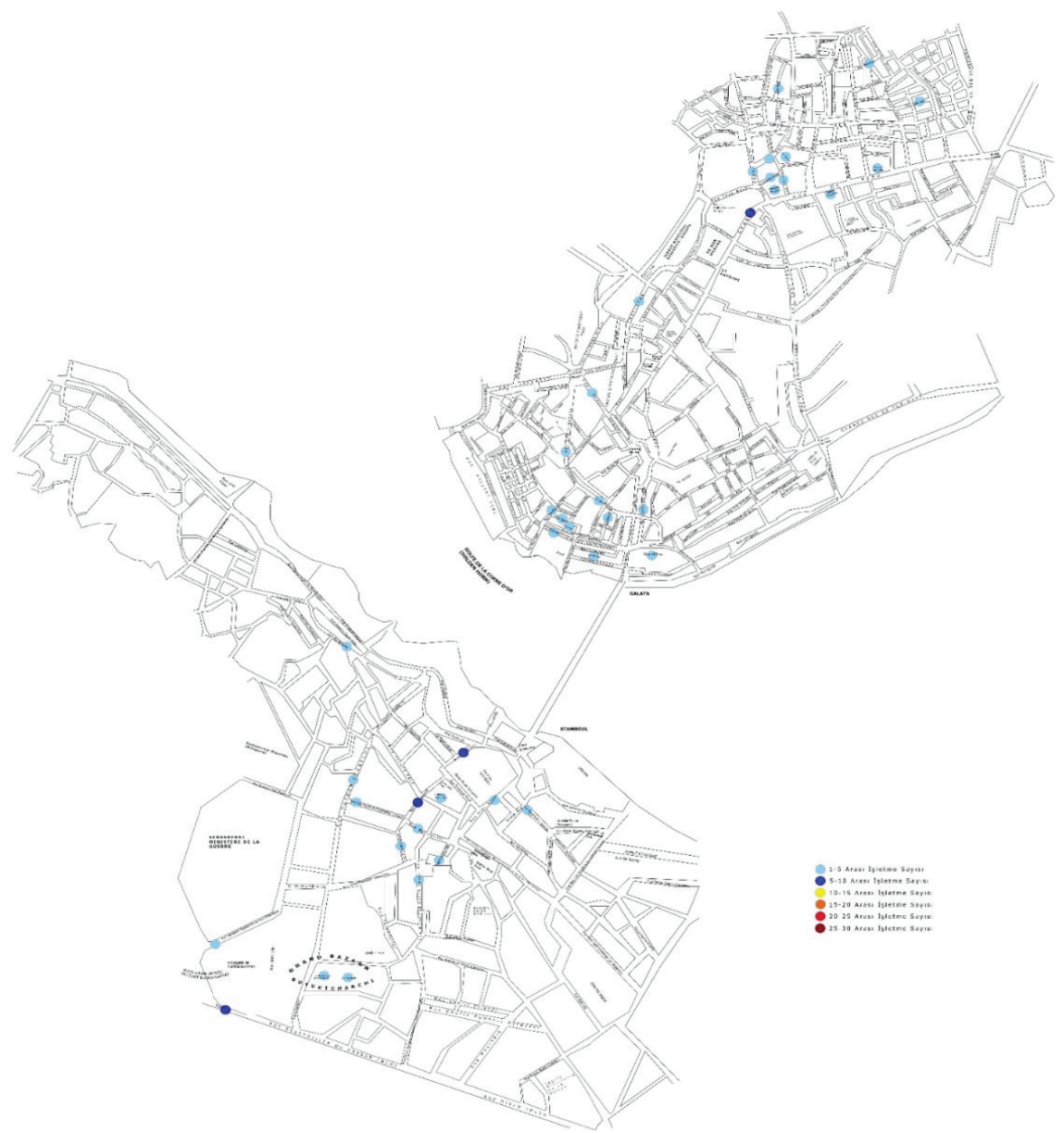

Şekil 9. 1892/1893-1900 yılları arasında Şark Ticaret Yıllıklarına ilan veren işletmelerin yerleşimi (Yazar Zeynep FIRAT EZENCİ tarafindan oluşturulmuştur.)

1901-1909 yılları arasındaki Galata bölgesindeki kümelenmenin, 1892/1893-1900 yılları arasındaki yoğunluktan fazla olduğu belirlenmiştir. Pera bölgesinde yer alan ve Grande Rue de Pera (İstiklal Caddesi) üzerindeki Place du Tunnel (Tünel Meydanı) çevresinde bir kümelenmenin bulunduğu tespit edilmiştir. Galata'dan Pera'ya geçmek isteyen kişilerin Tünel İstasyonunu kullanması sayesinde, işletmelere 
ulaşımının kolaylaşması ile yoğunluğun bu bölgede oluştuğu düşünülmektedir. Pera bölgesindeki yoğunluğun Grande Rue de Pera ve Lycee Imperial de Galata-Serai (Galatasaray Lisesi) çevresindeki pasajlarda oluştuğu harita üzerinde gözlemlenmiştir. Stamboul bölgesinde yer alan diğer işletmeler ise belirli alanlarda kümeleşerek bir araya geldikleri belirlenmiştir. Ancak bu kümelenme biçiminin yoğun olmadığ 1 tespit edilmiştir. Bu durum Şekil 10.'da görülmektedir.

1901-1909 yılları arasında toplam 107 işletme ilan vermiştir.

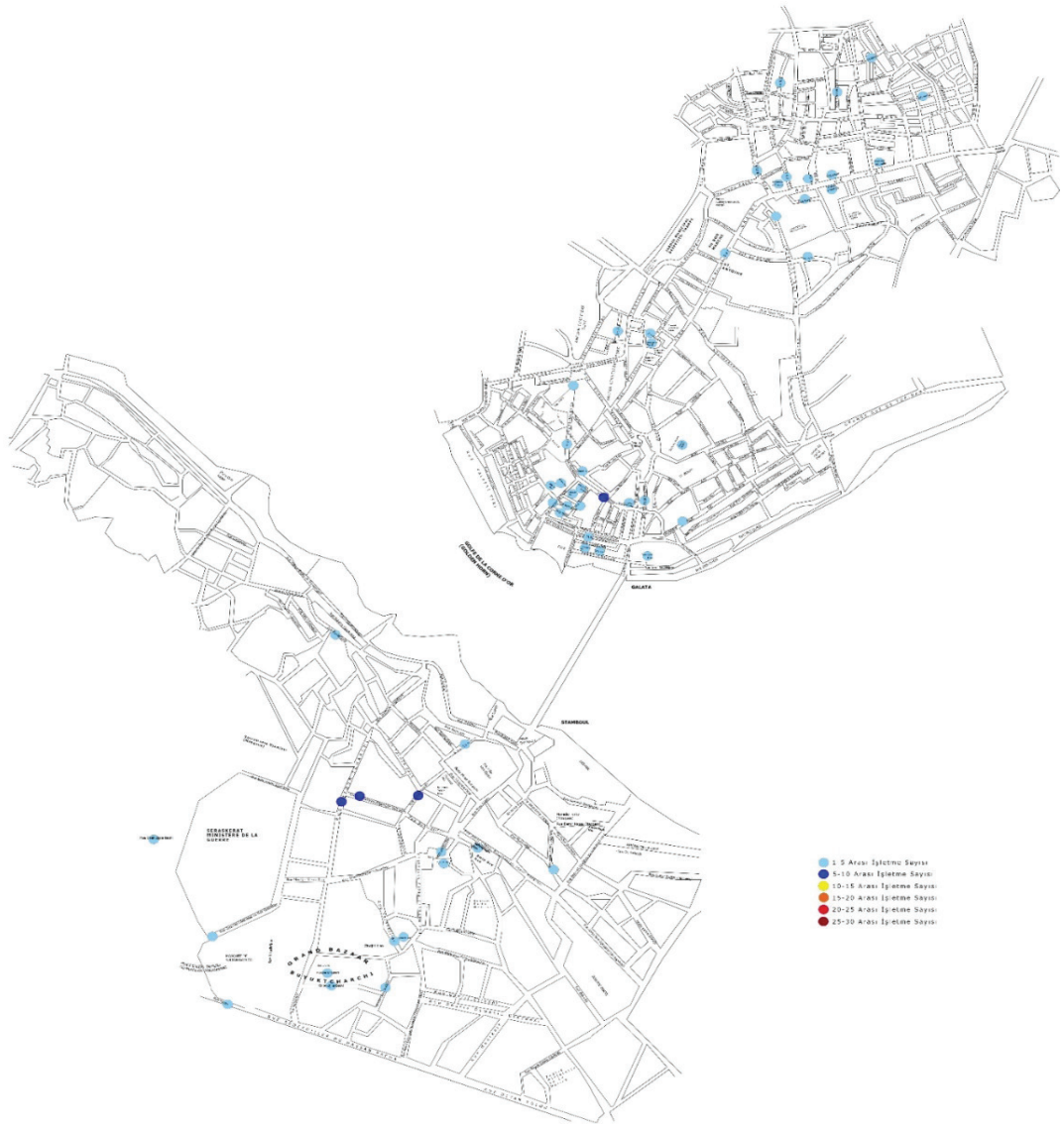

Şekil 10. 1901-1909 yılları arasında Şark Ticaret Yıllıklarına ilan veren işletmelerin yerleşimi (Yazar Zeynep FIRAT EZENCİ tarafından oluşturulmuştur.) 
Stamboul'da işletmelerin belirli kümeler halinde oluşturdukları yoğunluğun 1912-1914 yılında azaldığı ve hanlara dağıldığı tespit edilmiştir. Galata bölgesinde ise belirli bir artışın oluştuğu gözlemlenmiştir. Yoğunluk 1900-1909 yılları arasında Rue Perchembe Pazar (Perşembe Pazarı Sokak) ve çevresinde iken, 1912-1914 yılları arasında Rue Voivoda (Bankalar Caddesi) ve Voivoda'ya çıkan ara sokaklar üzerinde kümelendiği belirlenmiştir. Pera bölgesinde ise Grande Rue de Pera üzerinde aydınlatma aygıtları satan işletmelerin yoğunlaştığ 1 belirlenmiştir. Bu harita Şekil 11.'de görülmektedir.

1912-1914 yılları arasında toplam 119 işletme ilan vermiştir.

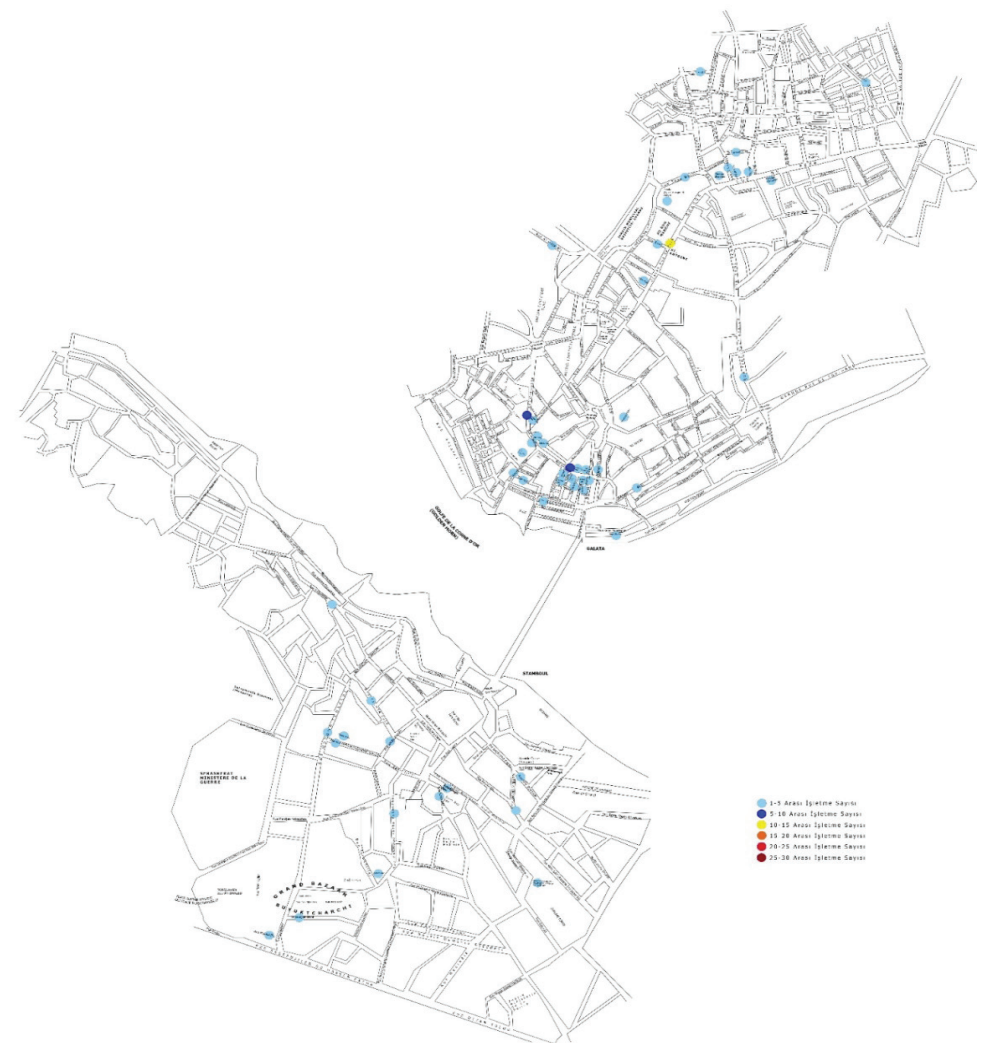

Şekil 11. 1912-1914 yılları arasında Şark Ticaret Yıllıklarına ilan veren işletmelerin yerleşimi (Yazar Zeynep FIRAT EZENCİ tarafindan oluşturulmuştur.) 
1921-1930 y1lları arasında Stamboul bölgesinde ilan veren işletmelerin sayısı ve yoğunluğunun 1912-1914 yılına oranla artışa geçtiği saptanmıştır. Rue Rıza Pacha (Rıza Paşa Caddesi) üzerindeki yoğunluğun, Achir Effendi Kutuphanessi Hopiar Mahallesi (Aşir Efendi Caddesi)'ne kadar devam ettiği ve bu bölgedeki hanlar etrafında yoğunlaştığ 1 tespit edilmiştir. Stamboul bölgesindeki bir diğer kümelenme örneği Kapalı Çarşı ve çevresinde yer almaktadır.

1921-1930 y1lları arasında Galata bölgesinde aydınlatma aygıtı ve teknolojisi satışı yapan birçok işletmenin yer aldığı belirlenmiştir. $\mathrm{Bu}$ yıl aralığında yer alan işletmelerin Rue Voivoda (Voyvoda Caddesi), Rue Hezaréné, Rue Yéni-Yol ve bu caddeleri çevreleyen hanlarda yer aldıkları tespit edilmiştir. Pera'da ise Place Du Tunnel'den (Tünel Meydanı) itibaren Grande Rue de Pera caddesi boyunca, aydınlatma aygıtı satışı ve elektrik teknolojisi üzerine deneyimli işletmelerin yoğunlaştığı tespit edilmiştir. Bu yoğunluk Şekil 12.'de görülmektedir. 1921-1930 yılları arasında toplam 311 işletme ilan vermiştir. 


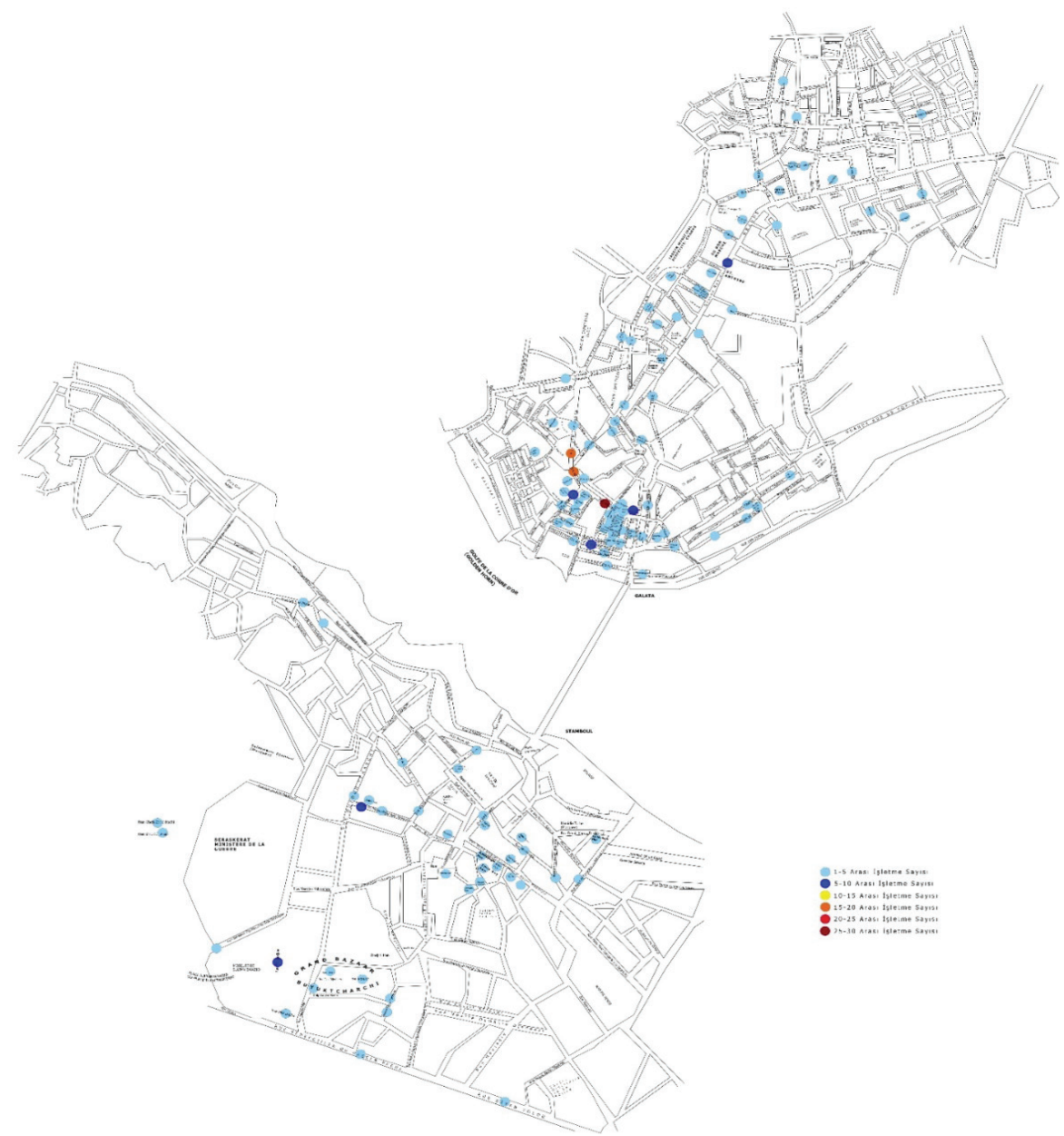

Şekil 12. 1921-1930 yılları arasında Şark Ticaret Yıllıklarına ilan veren işletmelerin yerleşimi (Yazar Zeynep FIRAT EZENCİ tarafından oluşturulmuştur.)

1922-1930 yılları arasında Şam Rehberlerine ilan veren işletmelerin sayısı, Şark Ticaret Yıllıklarına ilan veren işletme sayısından daha azdır. Bu sebeple, 1920-1930 yılları arasında Şark Ticaret Yıllıklarına ilan veren işletmeler için oluşturulan yoğunluk haritası ile aynı yılları kapsayan Şam Rehberleri için oluşturulan yoğunluk haritasında 
farkl11ıklar mevcuttur. Şam Rehberleri için oluşturulan yoğunluk haritası Şekil 13.'de gösterilmiştir.

Şam Rehberlerinde ilan veren işletmelerin Stamboul ve Pera bölgelerine göre daha çok Galata bölgesinde yoğunlaştığı tespit edilmiştir.

1922-1930 yılları arasında toplam 42 işletme ilan vermiştir.

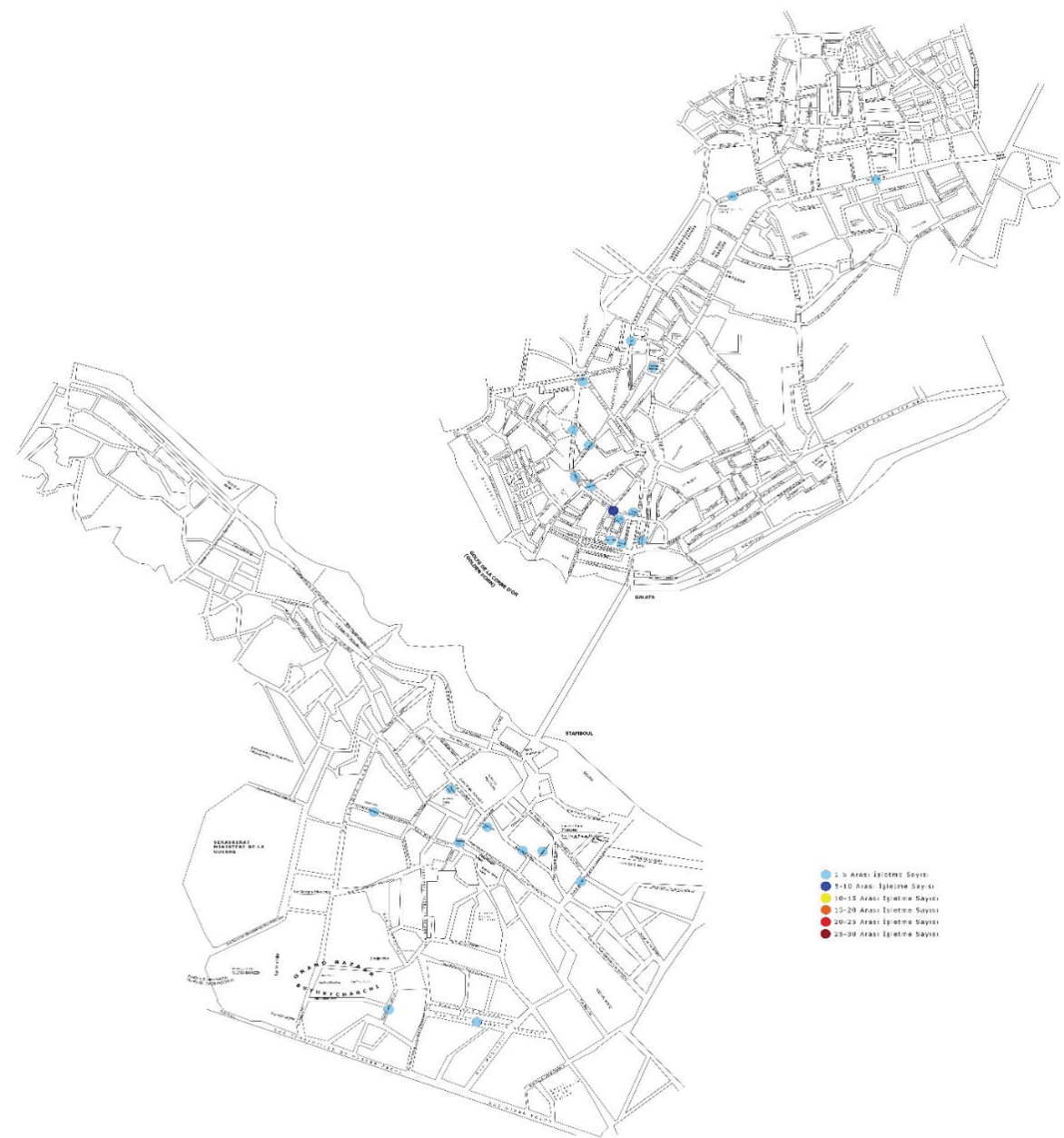

Şekil 13. 1922-1930 yılları arasında Şam Rehberi içerisinde ilan veren işletmelerin yerleşimi (Yazar Zeynep FIRAT EZENCİ tarafından oluşturulmuştur.) 
Şark Ticaret Yıllıklarının lamba üreticileri açısından ele alınmasının sebebi; çalışmanın dahilinde yer alan bu üretici ve tüccarların kayıtlarının yeterince detaylı ve düzenli olarak tutulmaması ve tutulan kayıtların sadece yıllıklar bazında olmasıdır.

\section{Değerlendirme ve Sonuç}

Enerji kaynaklarının yıllar içerisinde değişimi ile yapay aydınlatma elemanlarında çeşitli gelişimler yaşanmıştır. Yaşanan bu değişimler ilk olarak Osmanlı Devleti'nin üst düzeydeki kişileri tarafından kullanılan mekânlarda görülmüştür. Teknolojilerin ve ürünlerin değişimi ile yaşam tarzında çeşitli gelişimler ve farklılaşmalar yaşanmıştır. Yüksek statülü aileler ve üst düzey yetkililer, Batılı yaşama sahip olma arzusu ile batıyı yansıtan mobilyaları tercih etme eğiliminde olmuşlardir.

Osmanlı'daki bu modernleşme eğilimi halkın belli bir kesiminde görülürken; orta ve alt sınıfa ait tabakada geleneksel Osmanlı stilinden ürünlerin ve yerleşim biçimlerinin tercih edilmeye devam edildiği görülmüştür. Üst düzey kişilerin birbirlerinden etkilenerek, bulundukları mekânları Batılı tarzdaki mobilyalarla döşedikleri ve dönemin son teknoloji ürünlerini tercih ettikleri seçilen aydınlatma elemanlarından okunabilmektedir.

Osmanlı Devleti, 19. Yüzyılın ikinci yarısından itibaren bir batılılaşma sürecine girmiştir. Ancak Osmanlı Devleti bu dönem itibariyle gerileme dönemi içindeydi ve modernleşme hareketlerine rağmen çeşitli zorluklar yaşamaktaydı. Bu zorluklardan biri İngiltere'de ortaya çıkan ve tüm Avrupa'ya hızla yayılan sanayi devrimi idi. Osmanlı Devleti'nin yaşadığı iktisadi, siyasi ve ekonomik problemler sebebi ile sanayi devrimi, ülkeye geç sayılabilecek bir zamanda girmiştir.

Osmanlı Devleti yanlış yönetilen ekonomi politikaları sebebi ile hızla maddi olarak çöküşe giderken, bir dizi sanayileşme hamleleri ile bu durumu bertaraf etmeye çalışmıştır. Bu sanayi hamlelerinden biri 
değişen enerji kaynaklardır. Osmanlı Devleti, Avrupa'daki büyük ve modern şehirlerin bir benzerini yabancıların yoğunlukta olduğu Pera bölgesine uygulamayı denemiş ve bu amaç için tüm cadde 1şıklandırilmıştır.

Osmanlı Devleti'nin sanayileşme hamleleri ile y1llar içerisinde ve Avrupa'ya yakınlaşma isteği doğrultusunda, çeşitli anlaşmalar yapılmıştır. Bu anlaşmalar ile Osmanlı Devleti Avrupa'da sanayi malları için açık pazar konumuna gelirken, teşkilatlara bağlı esnaf kolları bu durumdan zarar görmüştür. Zanaat ve el emeği ile geçimini sağlayan esnaf, sanayi devrimi itibariyle ülkeye gelen yeni teknoloji mallar, ürünler ve makineler ile rekabet edememiş ve tüketici talepleri karş1sinda istenileni verememiştir.

Osmanlı Devleti içerisinde yetişen genç ve yenilikçi bürokratlar çöküş içerisindeki Osmanlı Devleti'nin kurtuluşunun Batılı pazarlar ile birlik olması ile aşılabileceğini belirtmişlerdir. Bu doğrultuda yapılan anlaşmalar sonucunda Batılı tüccarlar için büyük kolaylıklar sağlanırken, yerli esnaf kendine yetemez hale gelmiştir. Batılı tüccarlara hammadde ve ürün ucuza temin edilirken, esnafın böyle bir ayrıcalığı bulunmamaktaydı. Bu sebeple yerli esnafin ürettiği mallar pahalı ve üretimi zaman isteyen ürünler olduğu için halk, Batılı tüccarların ithal ettiği ucuz ve yeni stil ürünlere rağbet etmiştir.

İthal ürün tercihinin yoğun olmasının sebebi ise; elçilikler ile elçiliklerde çalışan kişilerin ailelerinin Batılı ürün tercihi olduğu düşüncesidir. $\mathrm{Bu}$ durumun sebepleri ise;

1. Yabancıların Batılı ürünlere özlem duyması,

2. Yabancilara ev hissiyatı vermesi,

3. Türk tipi ailelerin Galata bölgesine taşınması ile artan gösteriş ve modernleşme merakı olabileceği sayılabilir.

Buradan şu sonuç çıkartılabilmektedir;

- Stamboul: geleneksel üretim yöntemlerini kullanmaya devam ederek, eski gücünü kaybeden bir esnaf teşkilatlanması birliğini koruma çabası içerisinde bulunan üretici ve tüccarların iş yaptığ 1 
bölge olarak öne çıkmaktadır. Ayrıca toptan ve perakende satışın yapıldığı bir üretim merkezi olarak görülebilir.

- Galata ve Pera: Yeni ticaret ve satış anlayışları doğrultusunda, lüks ithal mallar satan mağazalardan oluşan bir satış merkezi olarak görülebilir.

Çalışmanın geçmiş dönemler ile ilgili bağlantısı yapıldığında, öncelik olarak Stamboul ve çevresinde zanaat temelli bir kümelenmeye rastlanılmıştır. Stamboul'a ek olarak Galata ve Pera'da da işletmelerin kümelenmeye başladığı belirlenmiştir. Bu dönem 19. Yüzyıl sonu, 20. Yüzyılın ilk yılları olarak belirtilebilir. Belirtilen yıllar içerisinde Şişhane'de mezarlık alanları (Petit Morts) bulunmaktadır ve altyapıda yapılan yeni düzenlemeler, bu bölgede faaliyete tam olarak geçmemiştir. Bu sebeple bahsi geçen tarih aralığında aydınlatma üretici ve tüccarları kümelenmesine rastlanmamıștır. 20. Yüzyıldan itibaren geleneksel üretim ve satışın yerini Batılı ürünler almış ve bu sebeple Stamboul'da bulunan zanaat temelli kümelenme yapısı bozularak Galata ve Pera'ya doğru kaymıştır. Bu dönem Altıncı Daire-i Belediye'nin faaliyete geçtiği ve belediye binasının bulunduğu bölgenin de altyap1 olarak hareketlendiği tespit edilmiştir. Galata bölgesinde yer alan Osmanlı Bankası ve bu bankanın çevre bölgesi (Voyvoda/Bankalar Caddesi) üzerinde belirli bir kümeleşme olduğu belirlenmiştir. Bunun sebebi ise, o dönem içerisinde yer alan idari ve iktisadi gelişmelerdir. Ancak y1llar içerisinde Osmanlı Devleti'nin gücünü kaybetmesi ve dağılan Osmanlı Bankası ile bu bölge eski hakimiyetini yitirmiştir. Ayrıca bu alanda kiraların yüksek oluşu ve yabancı sermayedarların Osmanlı'nın stabil olmayan koşulları çerçevesinde bu alanlardan çıkmaya zorlamıştır. Fakat Pera halen daha bir cazibe merkezidir ve bu merkeze en yakın bölge eskiden mezarlığın da bulunduğu Petit Morts ve çevresidir. İlerleyen yıllarda kaldırılan bu mezarlık alanı, dönüşüm geçirerek yeni bir işletme kümelenmesini doğuracaktır.

Araştırma kapsamında ele alınan Şark Ticaret Yıllıkları ile Şam Rehberlerinde ilan veren işletmelerin büyük bir kısmının yalnızca ithal malların satışı üzerine çalıştıkları belirlenmiştir. Üretim aşamasında 
yer alan işletmeler geleneksel üretim yöntemleri ile ürün ortaya çıkaran işletmelerdir.

Çalışma içerisinde yararlanılan yazılı kaynaklar olan Şark Ticaret Yıllıkları ile Şam Rehberlerinde aydınlatma ile ilgili olan başlıklar taranmıştır. Bu başlıklar içerisinden yalnızca "Electricité" ve "Electricens" başlıklarında aydınlatma ürün ve parçası haricinde satış yapan kişiler yer almaktadır. Bu başlıkların taranmasının sebebi, elektriğin 1920'ler itibari ile önem kazanması ve işletmelerin yavaş yavaş bu alana doğru kayarak elektrik ile ilgili başlıklar altına yönelmesidir. $\mathrm{Bu}$ sebeple elektrik ile ilgili başlıklar altında elektrikli aletler üzerine satış yapan firmalar da listelenmiştir.

Şark Ticaret Yıllıkları 1880-1930 yılları arasında taranmıştır. 1880-1910 yılları arasında başlıkların detaylandırıldığı ve çeşitlendirildiği görülmüştür. Ancak 1910-1930 yılları arasında ise başlıklarda detaylandırma ve çeşitliliğin azaldığı belirlenmiştir. 1910-1930 yılları arasında detaylı ve iş tanımının takibini yapmayı kolaylaştıran başlıklar yerine genel başlıklar kullanılmıştır. Genel başlıklar olarak, Appareils d'éclairage başlığı ile elektrik ile ilgili başlıkların (Electricité ve Electricens) ön plana çıktığı görülmektedir. Başlıklarda çeşitliliğin ve detaylandırmanın azalması ile ilan veren işletmelerin uzmanlık alanları ve iş tanımlarının bilgisine ulaşmak zorlaşmıştır. Ancak bu durum, ürün yelpazesinin çeşitlendiği ve artışa geçtiği olarak değerlendirilebilir. İşletme sahibi enva çeşit ürün satışı yapmaya başladığında, sattığı ürüne özgü başlığı bulamadığı ve farklı başlıklar altında ilan vermektense tek bir başlık altında kendini ifade etmek istediği düşünülebilir. Ayrıca işletme sahibi için farklı başlıklar altında ilan vermek yerine tek bir başlık altında ilan vermek daha ekonomik bir yol olarak gözükmektedir. Bu sebeple ürün yelpazesi genişleyip, ürün çeşitliliği arttıkça; başlık çeşitliliği azalmıştır denilebilmektedir.

Şark Ticaret Yılıkları ve Şam Rehberleri incelendiğinde, küçük ve orta ölçekli sayılan işletmeler zaman içerisinde artışa geçmiş ve belirli bölgelerde kümelenmişlerdir. İşletmelerin artışı ile ürüne ulaşmak kolaylaşmış ve ürünler çeşitlenmiştir. Bunun haricinde büyük ve katlı 
mağazaların açılması ve yayılmasıyla rekabet hızlanmıştır. Büyük mağazalar ürün kalitesini arttırmışlar ve Avrupa' dan lüks tüketim ürünlerini getirmeye başlamışlardır. Küçük işletmeler ise, büyük mağazaların satışını yaptığı lüks tüketim ürünler ile rekabet etmeye çalışmıştır. Bunun sayesinde ürünlerin kalitesi ve çeşitliliği artmıştır. Tüketicinin ulaşabileceği ürün potansiyelindeki artış ile iç mekânda çeşitli değişimler ve dönüşümler yaşanmıştır.

Çalışmanın 19. ve 20. Yüzyıl dönemleri içerisinde yer alan Osmanlı Dönemi ve erken Cumhuriyet dönemi sanayileşme hamlelerine 1şık tutması amaçlanmıştır. Bu amaç doğrultusunda; Galata, Pera ve Stamboul bölgelerinin sanayileşme izleri takip edilmiş, aydınlatma üretici ve tüccarlarına ulaşılarak bir dönemin üretim mirasının haritası çıkarılmış ve zamandizini oluşturulmuştur.

\section{Kaynakça}

[1] Y. Semiz, «1923-1938 Döneminde Türkiye'nin Sanayi Politikası,» Türkler, cilt 17, pp. 710-718, 2002.

[2] G. Karahüseyin, Bir Döneme Işık Tutanlar 19. Yüzyıl Osmanlı Saraylarında Aydınlatma Araçları Koleksiyonu, İstanbul: TBMM Milli Saraylar Daire Başkanlığ $1,2009$.

[3] Ö. Oral, Osmanlı Tereke Kayıtlarındaki İ̧̧ Mekan İthal Aydınlatma Eşyaları, Ankara: Ankara Üniversitesi, Sosyal Bilimler Enstitüsü, Sanat Tarihi Anabilim Dal1, 2016.

[4] K. Mortan ve Ö. Küçükerman, Çarşı, Pazar, Ticaret ve Kapalıçarşı, E. Yalçın, Dü., İstanbul: Türkiye İş Bankası Kültür Yayınları, 2010.

[5] M. S. Kütükoğlu, Tarih Araştırmalarında Usül, 2. dü., Ankara: Türk Tarih Kurumu, 2014.

[6] M. Kozak, Bilimsel Araştırma: Tasarım, Yazım ve Yayım Teknikleri, 1. Baskı dü., Ankara: Detay Yayıncılık, 2014.

[7] N. Karasar, Bilimsel Araştırma Yöntemi, Ankara: Nobel Yayın, 2017.

[8] İ. Karakaya, «Bilimsel Araştırma Yöntemleri,» \%1 içinde Bilimsel Araştırma Yöntemleri, A. Tanrı̈ğğen, Dü., Ankara, Anı Yayıncılık, 2014, pp. 55-84.

[9] Milli Saraylar, «Dolmabahçe Sarayı,» 2019. [Çevrimiçi]. Available: http:// www.millisaraylar.gov.tr/saraylar/dolmabahce-sarayi. 
[10] TBMM Milli Saraylar Daire Başkanlığı, Milli Saraylar Aydınlatma Araçları Koleksiyonu, İ. Yücel, Dü., İstanbul: TBMM Milli Saraylar Daire Başkanlığ1 Yayını, 1998, pp. 4-125.

[11] D. Demirarslan, «Osmanlı’da Modernleşme/ Batılılaşma Sürecinin İç Mekân Donanımına Etkileri,» Erdem, cilt 15, no. 45-46-47, pp. 35-66, 2007.

[12] F. İrez, XIX. Yüzyıl Osmanlı Saray Mobilyası, Ankara: Atatürk Kültür Dil Tarih Yüksek Kurumu Atatürk Kültür Merkezi, 1988, p. 136.

[13] A. Derin Öncel, Apartman: Galata'da Yeni Bir Konut Tipi, İstanbul: Institut français d'études anatoliennes/ IFEA Kitap yayınevi, 2010, p. 421.

[14] N. Akın, 19. Yüzyılın İkinci Yarısında Galata ve Pera, Ö. Ciravoğlu, Dü., İstanbul: Literatür Yayıncılık, 2011.

[15] TBMM Milli Saraylar Daire Başkanlığı, Milli Saraylar 1993, Ankara: TBMM Vakfi, 1993.

[16] Y. S. Tezel, Cumhuriyet Döneminin İktisadi Tarihi: (1923-1950), Ankara: Yurt Yayınları, 1982.

[17] S. R. Kayserilioğlu, M. Mazak ve K. Kon, Osmanlı'dan Günümüze Havagazının Tarihçesi, cilt 3, İstanbul: İGDAŞ Genel Müdürlüğü, 1999.

[18] H. K. Sirel, 3. Istanbul Tasarım Bienali: Biz Insan Mıyız? Türümüzün Tasarımı 2 Saniye, 2 Gün, 2 Yll, 200 Yll, 200.000 Yll, P. Derviş, Dü., İstanbul, Beyoğlu: Studio-X, 2016.

[19] M. Gül, Modern İstanbul'un Doğuşu: Bir Kentin Dönüşümü ve Modernizasyonu, B. Sanc1, Dü., İstanbul: Sel Yayınc1lık, 2018.

[20] Ö. Küçükerman, «1847'den 1997'ye Siemens'in 50. Y1lı (Türkiye Bölümü),» Eylül 1997. [Çevrimiçi]. Available: https://www.onderkucukerman.com/tr/ 1847den-1997ye-siemensin-150-yili-turkiye-bolumu/. [Erişildi: 2019].

[21] Ş. Pamuk, 100 Soruda Osmanl-Türkiye İktisadi Tarihi 1500-1914, Beşinci Baskı dü., İstanbul, Beyoğlu: Gerçek Yayınevi, 1999.

[22] C. Sezgin, Dü., Sanayi Devrimi Yıllarında Osmanlı Saraylarında Sanayi ve Teknoloji Araçları, TBMM Matbaası dü., İstanbul: TBMM Milli Saraylar Daire Başkanlığı, 2004.

[23] İ. Tekeli , «Türkiye'de Bölgesel Eşitsizlik ve Bölge Planlama Yazıları,» Tarih Vakfi Yurt Yayınları, 2008.

[24] E. C. Clark, «Osmanlı Sanayi Devrimi,» \%1 içinde Osmanlılar ve Batı Teknolojisi Yeni Araştırmalar Yeni Görüşler, İstanbul, İstanbul Üniversitesi Edebiyat Fakültesi Yayınlar1, 1992, pp. 37-52.

[25] N. Özdemir, Türkiye'de Elektriğin Tarihsel Gelişimi (1900-1938), Ankara: T.C. Ankara Üniversitesi Türk İnkılap Tarihi Enstitüsü, 2011.

[26] Z. Toprak, Türkiye'de Milli İktisat (1908-1918), Ankara: Yurt Yayınları, 1982. 
[27] U. Gülsoy ve B. Nazır, Dersaadet Ticaret Odası 1882-1923, cilt Birinci Nokta Basım, Ş. IVlemiş, Dü., İstanbul: İTO Yayınları, 2009.

[28] A. Kal’a, «Osmanlı Esnafı ve Sanayisi Üzerine Yapılan Çalışmalarla İlgili Genel Bir Değerlendirme,» Türkiye Araştırmaları Literatür Dergisi, cilt 1, no. 1, pp. 245-266, 2003.

[29] M. Kurt, K. Kuzucu, B. Çakır ve K. Demir , «19. Yüzyılda Osmanlı Sanayileşmesi Sürecinde Kurulan Devlet Fabrikaları: Bir Envanter Çalışması,» OTAM (ANKARA ÜNIVERSITESI OSMANLI TARIHI ARAŞTIRMA VE UYGULAMA MERKEZI), no. 40, pp. 245-277, 2016.

[30] T. Karauğuz, «Camc1lık ve İstanbul'da İlk Cam ve Billur Fabrikası,» Türk Kültürü, cilt X, no. 111, pp. 163-169, Ocak 1972.

[31] F. Çelikbaş, «İmparatorluğun Başkentinde,» \%1 içinde İstanbul Sanayi Odası'nın Altmışıncı Yılında Türk Sanayii, 3. Baskı dü., İstanbul, İstanbul Sanayi Odas1, 2015, pp. 19-23.

[32] N. Özgentürk, Sanayinin sonsuz 1şığında : İstanbul sanayi tarihi : yeniden üretim ekonomisi, yeniden sanayileşme, yeniden üretim kültürü, 2 dü., Z. Erpamir, Dü., İstanbul: İstanbul Sanayi Odası, 2017.

[33] A. Aksoy, Dü., Silahtarağa Elektrik Santrali 1910-2004, İstanbul: İstanbul Bilgi Üniversitesi Yayınları 177, 2007.

[34] TÜSİAD, «21. Yüzyıla Girerken Türkiye’nin Enerji Stratejisinin Değerlendirilmesi,» TÜSİAD, İstanbul, 1998.

[35] M. Yaşa, Cumhuriyet Dönemi Türkiye Ekonomisi 1923-1978, İstanbul: Apa Ofset Basımevi, 1980.

[36] T. F. Yücel, Cumhuriyet Türkiyesi’nin Sanayileşme Öyküsü, 1. Baskı dü., Ankara: Türiye Teknoloji Geliştirme Vakfi/TTGV, 2015.

[37] ETSM, «Endüstriyel Tasarım Sanal Müzesi Kronoloji,» 2012. [Çevrimiçi]. Available: http://www.etsm.org.tr/etsm/index.php?r=kronoloji/view\&id=150. [Erişildi: Nisan 2019].

[38] A. G. Ökçün, 1920-1930 Yılları Arasında Kurulan Türk Anonim Şirketlerinde Yabancı Sermaye, cilt Yayın No. 82, Ankara: Sermaye Piyasası Kurulu , 1997.

[39] Ç. D. Tağmat, Türkiye’nin 1929 Dünya Ekonomik Bunalımından Korunma Arayışları: Milli Sanayi Numune Sergisi, cilt I, D. v. T. Y. K. Atatürk Kültür, Dü., İzmir: Atatürk Araştırma Merkezi Yayını, 2015, pp. 721-738.

[40] H. İnalcık, «Osmanlı Dönemi,» \%1 içinde Dünden Bugüne İstanbul Ansiklopedisi, İstanbul, Türkiye Ekonomik ve Toplumsal Tarih Vakf1, 1994, pp. 350-352.

[41] A. Aktar, «Şark Ticaret Yıllıkları'nda "sarı sayfalar": İstanbul'da meslekler ve iktisadi faaliyetler hakkında bazı gözlemler, 1868-1938,» Toplum ve Bilim, no. 76, pp. 105-143, 1998. 
[42] B. Ergüder, İstanbul'un Finans Sermayesi Haritasinda Galata Hanları (18681945), İstanbul: İstanbul Üniversitesi, Sosyal Bilimler Enstitüsü, Maliye Ana Bilim Dalı, 2011.

[43] Atatürk Kitaplığı, [Çevrimiçi]. Available: http://ataturkkitapligi.ibb.gov.tr/kutuphane3/kartpostal/Krt_012029.jpg.

[44] B. Yağız ve A. Ağır, «XIX. Yüzyıl Sonu İstanbul’unda Batılı Tüketici Ürünlerinin Dolaşıma Girdikleri Kanallar ve Yarattıkları Hareketlenmeler: Şark Ticaret Yıllıkları Üzerinden Bir Araştırma,» Tasarım + Kuram, cilt 13, no. 24, pp. 3153, Aralık 2017.

[45] TDK, «Reklam,» 2019. [Çevrimiçi]. Available: https://sozluk.gov.tr/. [Erişildi: 3 Ocak 2021].

[46] O. Koloğlu, Basınımızda Resim ve Fotoğrafın Başlaması, İstanbul: Engin Yayınları, 1997.

[47] M. E. Yardımcı, S. Yılmaz Genç ve D. Süloğlu , «OSMANLI DEVLETI’NDE REKLAMIN TARIHSEL GELIŞSIMI VE EKONOMIYE İLK YANSIMALARI,» \%1 içinde International Congress of Management Economy and Policy, İstanbul, 2016.

[48] S. Öztürk, «Illanatlar, Türk Reklamcıllğı ve Sosyal Dönüşüm,» \%1 içinde İlan-l Ticaret Resimli İlanlar Perspektifinde Osmanlı'dan Cumhuriyet'e İstanbul Ticari Hayatt, İstanbul, İTO Yayınları, 2011, pp. 17-24.

[49] N. İleri, «AMELI ELEKTRIK DERGISI: DERSAADET ELEKTRIK VE TRAMWAY ŞIRKETLERI TARAFINDAN NEŞROLUNAN BIR MECMUA,» Institut Français d'Etudes Anatoliennes, 2 Mart 2017. [Çevrimiçi]. Available: https://www.canal-u.tv/video/ifea/ameli_elektrik_dergisi_dersaadet_ elektrik_ve_tramway_irketleri_taraf_ndan_ne_rolunan_bir_mecmua.34209. [Erişildi: 15 Ocak 2021].

[50] Salt Araştırma, «Ameli Electric - Ameli Elektrik,» [Çevrimiçi]. Available: https://archives.saltresearch.org/handle/123456789/129194.

[51] Salt Araştırma, «Ameli Electric - Ameli Elektrik,» [Çevrimiçi]. Available: https://archives.saltresearch.org/handle/123456789/129062.

[52] L. T. Baruh, «TRACING THE PAINTED-TRAY DEALERS IN ISTANBUL: a commercial and spatial reading,» \%1 içinde Rituals Of Hospitality: ornamented trays of the 19th century in Greece and Turkey, Athens, MELISSA PUBLISHING HOUSE, 2013, pp. 149-164.

[53] E. Eldem, Bankalar Caddesi. Osmanlı'dan Günümüze Voyvoda Caddesi, 1. Baskı dü., E. Eldem, Dü., İstanbul: Osmanlı Bankası Bankacılık ve Finans Tarihi Araştırma ve Belge Merkezi, 2000. 
[54] B. Ergüder, «İstanbul'un Finans Sermayesi Haritasında Galata Hanları (18681945),» İstanbyul Üniversitesi, Sosyal Bilimler Enstitüsü, Maliye Ana Bilim Dalı, İstanbul, 2011.

[55] N. Cemaloğlu, «Veri Toplama Teknikleri: Nicel-Nitel,» \%1 içinde Bilimsel Araştırma Yöntemleri, A. Tanrı̈̈̆ğen, Dü., Ankara, Anı Yayıncılık, 2014, pp. 133-164.

[56] A. Yıldırım ve H. Şimşek, Sosyal Bilimlerde Nitel Araştırma Yöntemleri, Ankara: Seçkin Yayıncılık, 2005, p. 366.

[57] Tarih Bilimi, «Tarih Biliminin Yöntemi,» 21 Eylül 2015. [Çevrimiçi]. Available: https://www.tarihbilimi.gen.tr/makale/tarih-biliminin-yontemi. [Erişildi: 2018].

[58] T. Akıncı, Beyoğlu: Yapılar, Mekanlar, İnsanlar (1831-1923), İ. Gürsoy, Dü., İstanbul: Remzi Kitabevi, 2018.

[59] Ö. Küçükerman, Sanayi ve Tasarım Yarışında Bir İmparatorluk İki Saray “Topkapı" ve "Dolmabahçe”, 1. bASKI dü., K. Tankuter, Dü., İstanbul: Yapı Kredi Yayınları, 2007.

[60] S. Eyice, «XVI. Yüzyılda Osmanlı Devleti'nin ve İstanbul'un Görünümü,» \%1 içinde Mimarbaşı Koca Sinan: Yaşadiğı Çăg ve Eserleri, İstanbul, Başbakanlık Vakıflar Genel Müdürlügüü, 1988, pp. 99-107.

[61] T. Aslan ve T. Yazar, "GELENEKSEL EL SANATLARI BAĞLAMINDA KÜLTÜR ÜRÜNLERİ OLARAK TÜRK CAM SANATI: SURNAME-İ HÜMAYUN ANALİİ,» Turkish Studies International Periodical For The Languages, Literature and History of Turkish or Turkic, no. 10/5, pp. 13-26, Spring 2015.

[62] Ö. Küçükerman, Türk Giyim Sanayiinin Tarihi Kaynakları, İstanbul: GSD Dış Ticaret A.Ş. Yayını, 1996, p. 65.

[63] Ö. Küçükerman, Cam Sanatı ve Geleneksel Türk Camcılığından Örnekler, Ankara: Türkiye İş Bankası Kültür Yayınları, 1985, p. 140.

[64] Büyük Larousse Sözlük ve Ansiklopedisi, Aydınlatma, cilt 3, İstanbul, Levent: İnterpress Basım ve Yayıncılık A.Ş., 1992.

[65] İ. Fitoz, Dolmabahçe Sarayı'nda “Avrupa Işıkları”, İstanbul: TBMM Milli Saraylar Daire Başkanlığı Yayını No:40, 2007.

[66] A. Temür ve A. O. Şirin, «Amisos’tan Boğa Başı Formunda Bir Kandil ve Kandelabrum,» Uluslararası Sosyal Araştırmalar Dergisi, cilt 11, no. 56, pp. 234$242,2018$.

[67] TDK, «Büyük Türkçe Sözlük-Mum,» 2019. [Çevrimiçi]. Available: http:// www.tdk.gov.tr/index.php?option=com_bts\&arama=kelime\&guid=TDK. GTS.5cc99feec4f7c9.30487353. 
[68] D. Kuban, «Aydınlatma,» \%1 içinde Dünden Bugüne İstanbul Ansiklopedisi, cilt 8, T. E. v. T. T. Vakfı, Dü., İstanbul, Ana Basım A.Ş., 1993, pp. 474-481.

[69] Wikipedia, «Wikipedia,»13 03 2020. [Çevrimiçi]. Available: https://en.wikipedia.org/wiki/Oil_lamp. [Erişildi: 1603 2020].

[70] Ana Brittanica Genel Kültür Ansiklopedisi, Argand Lambası, cilt 3, İstanbul: Ana Yayıncılık A.ş., 1988.

[71] Ana Brittanica Genel Kültür Ansiklopedisi, Gazyağı, İstanbul: Ana Yayıncılık A.Ş. , 1988.

[72] Z. Toprak, «Aydınlatma,» \%1 içinde Dünden Bugüne İstanbul Ansiklopedisi, İstanbul, Koçu Yayınları, 1993, pp. 476-481.

[73] A. Kebapçığlu, «Aydınlatmada Kullanılan En Yaygın Sözcüklerin Açıklamas1,» Eylül 2010. [Çevrimiçi]. Available: http://www.lumieredeloeil.com/lumiara/tr/glosstr.htm. [Erişildi: 2019].

[74] E. Erdem, «Sanayi Devriminin Ardından Osmanlı Sanayileşme Hamleleri: Sanayi Politikalarının Dinamikleri ve Zaafiyetleri,» Erciyes Üniversitesi İktisadi ve İdari Bilimler Fakültesi Dergisi, pp. 17-44, Temmuz-Aralık 2016.

[75] A. L. Aytar, «Dün, Bugün ve Yarın,» IETT Dergisi, no. 5, Şubat 1957.

[76] M. G. Polatoğlu, « İKİNCİ BEŞ YILLIK SANAYİ PLANI (1938-1942),» Atatürk Dergisi, cilt 6, no. 1, pp. 55-87, 2017.

[77] R. Mantran, 17. Yüzyılın İkinci Yarısında İstanbul, Ankara: Türk Tarih Kurumu Basımevi, 1990.

[78] F. Köprülü, Türk Edebiyatında İlk Mutasavvıflar, Ankara: Diyanet İşleri Başkanlığı Yayınları, 1984.

[79] A. N. Yüksel ve A. Göksel, «Bölgesel Kümelenme Örneği Olarak Ahilik Teşkilat1,» Ahi Evran Üniversitesi Sosyal Bilimler Enstitüsü Dergisi (AEÜSBED), cilt 6, no. 3, pp. 794-812, 2020.

[80] İ. Ortaylı, Türkiye teşkilat ve idare tarihi, Ankara: Cedit Neşriyat, 2010.

[81] K. Mortan ve Ö. Küçükerman , Çarşı, Pazar, Ticaret ve Kapalıçarşı, İstanbul: Türkiye İş Bankası Kültür Yayınları, 2010. 